2014-04-03

\title{
Cross-shelf exchange in the northwestern Black Sea
}

\author{
Zhou, F
}

http://hdl.handle.net/10026.1/9423

10.1002/2013JC009484

Journal of Geophysical Research: Oceans

American Geophysical Union (AGU)

All content in PEARL is protected by copyright law. Author manuscripts are made available in accordance with publisher policies. Please cite only the published version using the details provided on the item record or document. In the absence of an open licence (e.g. Creative Commons), permissions for further reuse of content should be sought from the publisher or author. 


\section{Journal of Geophysical Research: Oceans}

\section{RESEARCH ARTICLE Cross-shelf exchange in the northwestern Black Sea}

\subsection{2/2013JC009484}

Key Points:

- Cross-shelf break transports of volume, heat, and salt are quantified

- Exchange mechanisms by mesoscale eddy and wind-driven Ekman drift are analyzed

- Some exchange events are shown to cause a sharpening of the shelf break density front

Correspondence to:

G. Shapiro,

gshapiro@plymouth.ac.uk

Citation:

Zhou, F., G. Shapiro, and F. Wobus (2014), Cross-shelf exchange in the northwestern Black Sea, J. Geophys. Res. Oceans, 119, 2143-2164, doi:10.1002/2013JC009484.

Received 2 OCT 2013 Accepted 5 MAR 2014 Accepted article online 11 MAR 2014 Published online 3 APR 2014

\author{
Feng Zhou'1,2, Georgy Shapiro3 ${ }^{3}$ and Fred Wobus ${ }^{3}$ \\ ${ }^{1}$ State Key Laboratory of Satellite Ocean Environment Dynamics, Second Institute of Oceanography, State Oceanic \\ Administration, Hangzhou, China, ${ }^{2}$ Department of Ocean Science and Engineering, Zhejiang University, Hangzhou, China, \\ ${ }^{3}$ School of Marine Science and Engineering, University of Plymouth, Plymouth, UK
}

\begin{abstract}
The transports of water, heat, and salt between the northwestern shelf and deep interior of the Black Sea are investigated using a high-resolution three-dimensional primitive equation model. From April to August 2005, both onshore and offshore cross-shelf break transports in the top $20 \mathrm{~m}$ were $0.24 \mathrm{~Sv}$ on average, which is equivalent to the replacement of $60 \%$ of the volume of surface shelf waters (0-20 m) per month. Two main exchange mechanisms are studied: Ekman transport, and transport by mesoscale eddies and associated meanders of the Rim Current. The Ekman drift causes nearly uniform onshore or offshore flow over a large section of the shelf break, but it is confined to the upper layers. In contrast, eddies and meanders penetrate deep down to the bottom, but they are restricted laterally. During the strong wind events of 15-22 April and 1-4 July, some $0.66 \times 10^{12}$ and $0.44 \times 10^{12} \mathrm{~m}^{3}$ of water were removed from the northwestern shelf, respectively. In comparison, the single long-lived Sevastopol Eddy generated a much larger offshore transfer of $2.84 \times 10^{12} \mathrm{~m}^{3}$ over the period 23 April to 30 June, which is equivalent to $102 \%$ of the volume of northwestern shelf waters. Over the study period, salt exchanges increased the average density of the shelf waters by $0.67 \mathrm{~kg} \mathrm{~m}^{-3}$ and reduced the density contrast between the shelf and deep sea, while lateral heat exchanges reduced the density of the shelf waters by $0.16 \mathrm{~kg} \mathrm{~m}^{-3}$ and sharpened the shelf break front.
\end{abstract}

\section{Introduction}

Steep bathymetry at the shelf edge inhibits ocean-shelf exchange, as large-scale currents tend to flow along the contours of constant depth [Huthnance, 1995]. However, both theory and observations have demonstrated that the circulation is not in geostrophic balance along lateral ocean boundaries, in straits and overflows and in the upper mixed layer [Niiler, 2009]. Hence, ageostrophic features, such as mesoscale eddies, turbulent mixing, and Ekman transport, become the main agents to provide cross-shelf edge transport [Houghton et al., 1988; Brink et al., 1992; Sur et al., 1994; Ohlmann et al., 2001; Peliz et al., 2004; Huthnance et al., 2009; Kirincich and Barth, 2009].

Ocean margin fluxes between productive shelf waters and nutrient-rich deep ocean waters are not only important to carbon and nutrient budgets in the ocean, and thus do matter to global climate change, but are also essential to refresh the highly eutrophic coastal marine ecosystems [Bauer and Druffel, 1998; Pringle, 2001; Huthnance et al., 2002; Biggs et al., 2005]. A variety of physical and biogeochemical processes can modify the properties of shelf waters. Traditionally, the focus has been on the effect of river runoff [Caddy and Bakun, 1995]; however, recent studies show the significance of exchange with adjacent areas of deep ocean [see e.g., Biggs et al., 2005, and references therein].

There have been a number of experiments aiming at estimating the exchange between the shelf and the deep-sea region [Biscaye et al., 1994; Biscaye and Anderson, 1994; Matsuno et al., 2009; Piola et al., 2010]. Direct measurements of cross-shelf break exchange [Johnson and Chapman, 2011] are rare and difficult to conduct as the cross-shelf current is often much smaller than the along-shelf counterpart. The use of ocean circulation models proved to be a helpful supplement to in situ measurements and satellite observations [Dinniman et al., 2003; Serra et al., 2010; Zhao and Guo, 2011].

The estimates of exchange fluxes can vary dramatically. According to Biscaye et al. [1994], less than 5\% of biogenic particulate matter is exported from the Middle Atlantic Bight of the eastern North America continental shelf. Estimates for the Black Sea based on remotely sensed data are significantly higher; up to $40 \%$ of shelf waters could be replenished during the summer season by a single mesoscale eddy [Shapiro et al., 2010]. On 


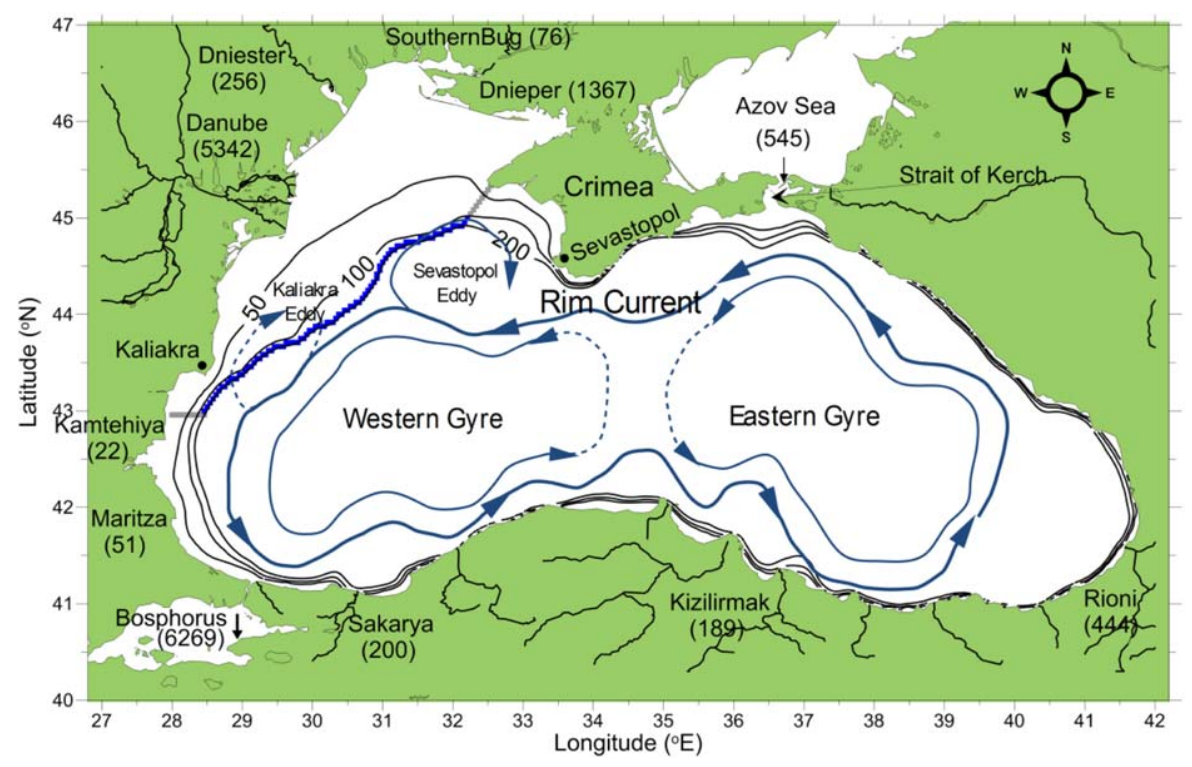

Figure 1. Geographic setting, main rivers, and topographic features of the Black Sea with solid contours representing bathymetry. The annual mean runoffs of the main rivers and discharges via the Kerch and Bosporus straits are shown in the parentheses (units: $\mathrm{m}^{3} / \mathrm{s}$ ). The boundary enclosing the northwestern shelf (the "fence") is composed of the shelf break following the $200 \mathrm{~m}$ isobath (line of blue squares) and two short segments connecting to the coast (gray squares) at the two ends of the line formed by blue squares. Schematic of the Rim Current, main gyres, and anticyclonic eddies are indicated by arrows, modified from that of Oguz et al. [1993].

the edge of the East China Sea, the cross-shelf volume transport showed significant seasonal variability, ranging from $0.5 \mathrm{~Sv}\left(1 \mathrm{~Sv} \equiv 10^{6} \mathrm{~m}^{3} \mathrm{~s}^{-1}\right.$ ) in summer to $3.0 \mathrm{~Sv}$ in autumn [Guo et al., 2006]. A model study of the Ross Sea shelf showed high values of the individual components of the cross-shelf transport, corresponding to different water masses and different depth ranges [Dinniman et al., 2003]. The yearly averaged onshore surface Ekman transport was $0.3 \mathrm{~Sv}$, while the offshore transport in the bottom Ekman layer was $0.8 \mathrm{~Sv}$, with short-term enhancements of up to 1-1.5 Sv. The long-term mean total transport onto the shelf from surface to bottom via a closed boundary was nearly zero (less than $10^{-2} \mathrm{~Sv}$ on average) due to mass conservation.

As well as in other parts of the ocean, across-shelf exchange in the Black Sea controls the quantities, transformation, and fate of materials discharged into the shelf by the rivers. The Black Sea is a unique marine environment, representing the largest land-locked basin in the world (Figure 1). Its general circulation pattern includes the Rim Current-a cyclonic flow located at the seaward side of the shelf break, and two subbasin cyclonic gyres sometimes called "Knipovich spectacles" [Bulgakov and Kushnir, 1996]. The drainage area of the Black Sea is about 2,000,000 km², which is nearly 5 times larger than its surface area, and covers almost a third of Europe. This results in a disproportionally large freshwater input making the Black Sea an estuarine-type basin. Large European rivers (the Danube, Dnieper, Southern Bug, and Dniester) discharge freshwaters into the northwestern (NW) shelf [Shapiro, 2009]. The rivers bring vast quantities of nutrients, leading to eutrophication of shelf waters and decline of the once flourishing Black Sea ecosystem [GEFUNDP report, 2006]. Exchanges across the NW shelf break provide a mechanism for the self-cleaning of the shelf waters, and hence the quantification of such exchanges is a highly important research topic.

The NW shelf and deep areas of the Black Sea differ significantly in terms of a number of characteristics. The concentration of chlorophyll $a$ (hereafter $\mathrm{Chl}-a$ ) is as high as $5-10 \mathrm{mg} \mathrm{m}^{-3}$ on the shelf, but is as low as $0.2-$ $0.5 \mathrm{mg} \mathrm{m}^{-3}$ in the open sea (Figure 2). The NW shelf is typically colder, fresher, and less dense than the open sea in both winter and summer (Figure 3). Hence, the intensity of across-shelf exchange is instrumental in smoothing, stabilizing, or enhancing the gradients of these parameters between the productive NW shelf and oligotrophic deep-sea region. An increase in the across-shelf exchange of salt would increase the salinity and density of the shelf waters, reduce the density contrast, and decrease the strength of the shelf break front. Reduction of the density front may initiate a positive feedback loop enhancing further across-shelf exchange that may destabilize the density structure of the Black Sea. On the other hand, an increase in the across-shelf exchange of heat would increase the temperature and reduce the density of the shelf waters, hence 


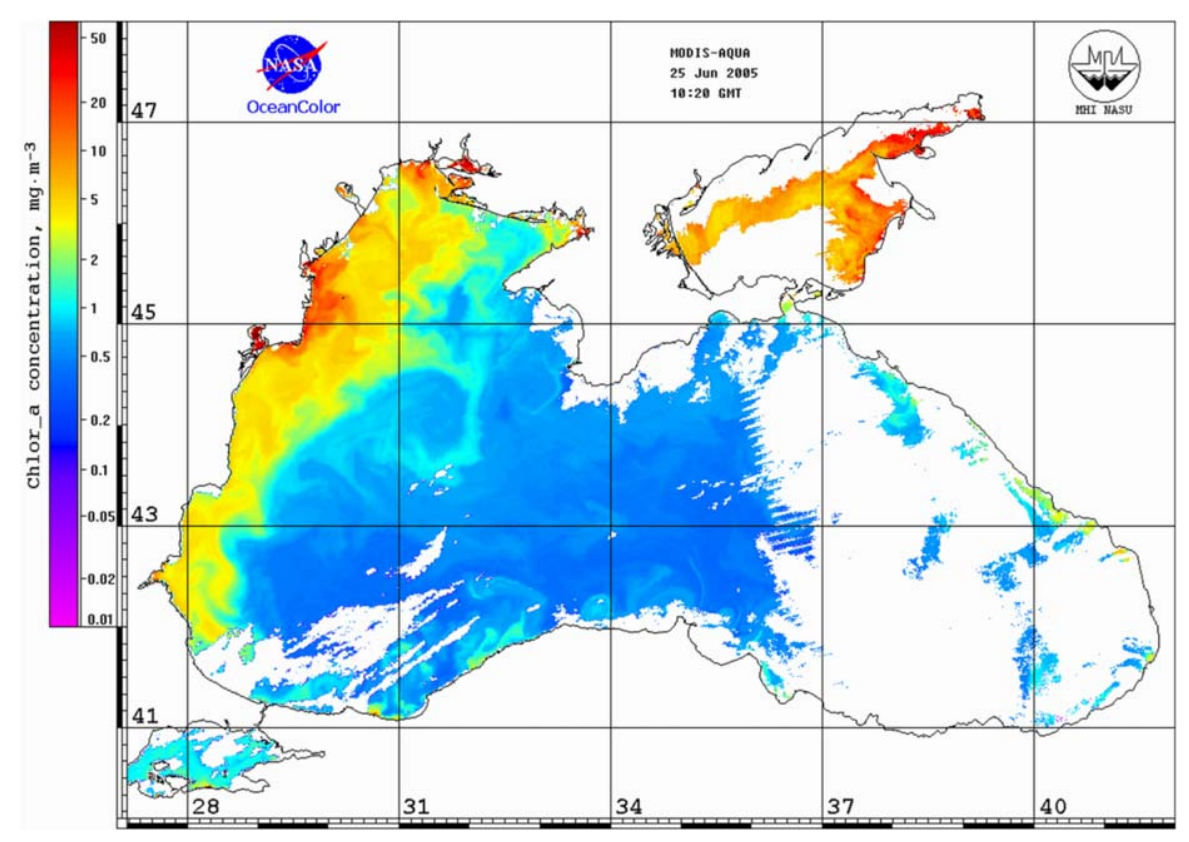

Figure 2. Satellite observed Chl- $a$ concentration in the Black Sea in June 2005. An anticyclonic eddy centered around $44^{\circ} \mathrm{N}, 31.5^{\circ} \mathrm{E}$ is seen to draw waters with high concentrations of Chl- $a$ from the biologically productive shelf into the deep Black Sea basin.

strengthening the shelf-edge density front and initiating a negative feedback loop, thus stabilizing the existing property pattern. The relative strength of the positive and negative feedbacks is difficult to assess based only on reasoning and patchy measurements. It needs quantitative estimates of exchanges along the whole NW shelf break for an extended period of time, which can only be achieved by ocean modeling.

The role of the anticyclonic eddies in cross-shelf exchange in the Black Sea has been highlighted in a number of publications [Blinkov et al., 2002; Zatsepin et al., 2003, and references therein]. A long-lived anticyclonic eddy with a nearly $113 \mathrm{~km}$ diameter was identified in June 1984 and thought to cause significant transport of water [Latun, 1990]. A radiance spectrum from SeaWiFS was used to identify vortex dipoles and diagnose the pattern of the exchange between coastal region and deep basin [Karabashev et al., 2006]. In summers of 1993 and 1998, anticyclonic eddies were traced persistently over the wide and relatively gentle slope; they contributed to cross-shelf exchange particularly between $43^{\circ} \mathrm{E}-45^{\circ} \mathrm{N}$ and $29^{\circ} \mathrm{E}-33^{\circ} \mathrm{E}$ [Ginzburg et al., 2002a, 2002b]. Anticyclonic eddies are fundamentally recurrent and quasi-stable, and can be reproduced by appropriate modeling [Korotaev et al., 2003].

However, previous research of cross-shelf exchange in the Black Sea was mostly restricted to a qualitative understanding of the underlying processes rather than quantitative estimates, except for Shapiro et al. [2010] that gave a quantitative estimate of the horizontal fluxes based on satellite imagery for the year 2005. Due to the nature of the available data, the study was limited in time (cloud-free conditions) and in vertical extent (the surface layer only).

This paper focuses on quantification of cross-shelf break fluxes in the NW shelf of the Black Sea during the spring-summer period of 2005 when weather condition was more favorable for remotely sensed data, to cover the main period of Chl- $a$ bloom. We use a high-resolution numerical model to estimate onshore and offshore fluxes in different depth ranges, with a particular emphasis on the transports in the surface eutrophic layer generated by Ekman drift and mesoscale eddies. We also investigate the locations of these transports and their temporal variability.

\section{Model, Data, and Methods}

The simulation is performed using the 3-D Nucleus for European Modeling of the Ocean model [Madec, 2008], which was further developed for operational forecast for shelf waters (hereafter NEMO_SHELF) 

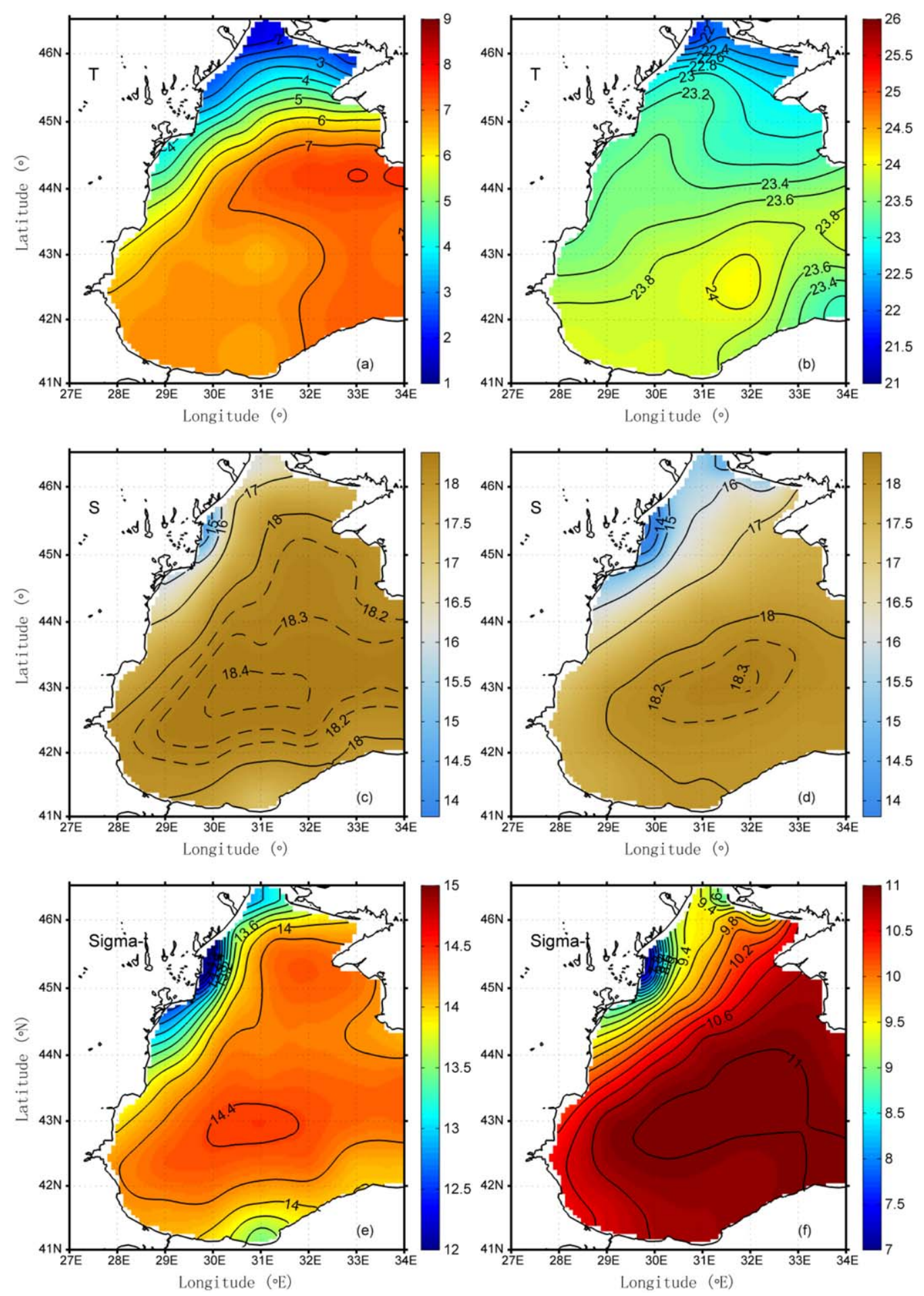

Figure 3. Climatological sea surface temperature $(T)$, salinity $(S)$, and density (Sigma-t). (a), (c), and (e) Winter (February). (b), (d), and (f) Summer (August). Note that the color bars are different for summer and winter charts. Redrawn after Suvorov et al. [2003].

[O'Dea et al., 2012]. The model has been thoroughly tested and validated across the Met Office [Edwards et al., 2012; O'Neill et al., 2012]. The configuration of NEMO_SHELF for the Black Sea has been optimized to better represent specific features of the Black Sea, for instance, with limited exchange with the world ocean, and significant river inflow [Shapiro et al., 2013]. 
For this study, the model covers the entire Black Sea (Figure 1), and is set up with $1 / 24^{\circ}$ horizontal resolution (approximately $3.3 \mathrm{~km}$ in the zonal and $4.6 \mathrm{~km}$ in the meridional directions) and a hybrid vertical coordinate system with a total of 33 layers. The 18 layers shallower than $100 \mathrm{~m}$ are represented by an enveloped s-coordinate system [Madec, 2008], which was a further development of the terrain-following vertical grid by Song and Haidvogel [1994], and the deeper layers are arranged horizontally in a z-coordinate. This configuration will be referred to as NEMO-BLS24. Further details of this configuration and its validation can be found in Shapiro et al. [2013]. The NEMO-BLS24 model was run in a "free" mode, i.e., without data assimilation.

The model was initialized to start from 1 January 2005 by interpolating monthly climatological temperature and salinity data for December and January from the Black Sea Atlas [Suvorov et al., 2003] and then generating the matching initial velocities using a "semidiagnostic adjustment method" [Sarkisian and Sündermann, 2009], also known as "diagnostic-prognostic adjustment" [Ezer and Mellor, 1994]. After the "diagnostic adjustment" the model was run in a fully prognostic mode, showing that the model adjusts itself to the "wind shock" well within approximately 30 days, in a full agreement with the finding by Ezer and Mellor [1994].

Chl- $a$ concentration was obtained from the Level-3 product of Medium Resolution Imaging Spectrometer (MERIS, http://oceandata.sci.gsfc.nasa.gov/MERIS/), and from the Moderate Resolution Imaging Spectroradiometer in Aqua satellite (MODISA), which was kindly provided by the National Space Agency of Ukraine (NSAU, http://dvs.net.ua/mp/index.shtml). MODISA incorporates local atmosphere corrections for the Black Sea. Although it is commonly accepted that the algorithm for calculating the concentration of Chl- $a$ has difficulties in highly turbid coastal water, we only use Chl- $a$ for qualitative estimates, i.e., as a tracer to identify the border between $\mathrm{Chl}-a$ rich shelf waters and oligotrophic waters of the deep basin. Sea surface temperature, processed by the NSAU based on data from the National Oceanic and Atmospheric Administration (NOAA) polar-orbiting environmental satellites 12 and 15-17, is used to compare the eddy position and migration with model results.

The meteorological data sets used to force the model were obtained from the National Center for Environmental Prediction (NCEP). They include 4 times daily data sets on air temperature, relative humidity, wind, precipitation, and downward long- and short-wave radiation. The meteorological data in a few grid boxes that cover both the eastern corner of the Black Sea and the high (more than $5000 \mathrm{~m}$ ) Caucasus Mountains are highly contaminated by the conditions over the mountains. These data points are replaced by extrapolation from the neighboring "sea-only" grid boxes.

The simulation includes 10 major rivers: the Danube, Dniester, Dnieper, Don, Kamtehiya, Maritza, Kizilirmak, Rioni, Southern Bug, and Sakarya (Figure 1). Exchange via Bosporus is described as a negative river discharge, representing a balance between the upper (outward) and lower (inward) flows. Daily river discharges into the Black Sea are interpolated from monthly climatological data sets [Jaoshvili, 2002].

The transport of water, salt, and heat between the shelf and deep-sea regions was calculated along an enclosed boundary (a "fence") approximating the $200 \mathrm{~m}$ isobath (Figure 1, blue squares) plus two short segments connected to the coast (Figure 1, gray squares). For each day, the total transport was calculated by integrating the individual daily averaged fluxes through the model grid boxes in the horizontal along the "fence" and in the vertical from surface to bottom. Partial transports were also calculated for the surface layer (top $20 \mathrm{~m}$ ) and the under-surface layer (from $20 \mathrm{~m}$ to the bottom). The $20 \mathrm{~m}$ level is approximately equal to the Ekman depth in summer [Oguz, 2008]. It is also close to the depth of the biologically active euphotic layer; for instance, the transparency of water in the offshore NW shelf is about 15-18 m [Zaitsev, 1992].

\section{Results}

Following the usual practice [Nezlin et al., 1999; Kopelevich et al., 2002; Shapiro et al., 2010], the satellite charts of Chl- $a$ concentration are used here as a useful tool to identify the front between chlorophyll-rich shelf waters and the deep-sea region, visualizing the meanders of the Rim Current and eddies (Figure 1). As an example, the MERIS Chl- $a$ distribution on 30 June 2005 (Figure 4a) shows a strong anticyclonic eddy centered near $31.24^{\circ} \mathrm{E}, 43.86^{\circ} \mathrm{N}$ with an approximate radius of $76 \mathrm{~km}$. The location of the eddy center and its 

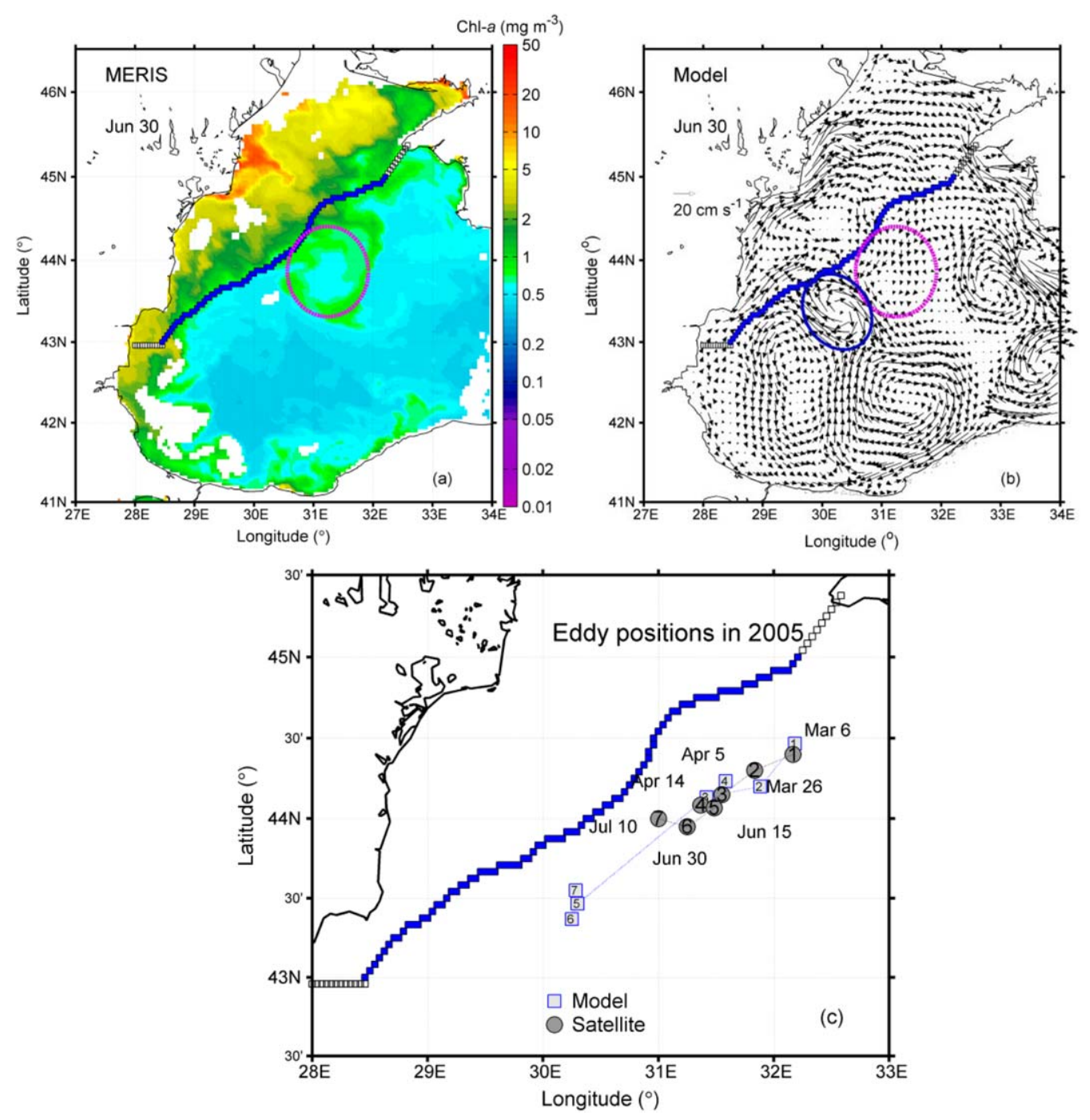

Figure 4. Comparison of the properties of the anticyclonic eddy identified from the satellite observations and simulated by the model. (a) Chl- $a$ concentration from MERIS, with the eddy schematically marked by the purple dotted line. (b) Modeled surface currents showing an eddy of comparable radius as in Figure 4a in a location close to the observed eddy (reproduced); the modeled eddy is schematically marked by the blue ellipse. (c) Positions of the eddy derived from the satellite observations (gray circles) and model (squares) in 2005. The plotted current vectors are averaged using nine neighboring grid points. The NW shelf is indicated the same way as in Figure 1.

propagation from 6 March to 10 July was derived using a set of satellite observed Chl- $a$ and SST charts, and is shown in Figure 4c. The eddy pathway was essentially parallel to the shelf break. During this period, the eddy center was always outside the shelf with a mean separation of $50 \mathrm{~km}$ from the shelf break, while its mean zonal radius was about $49 \mathrm{~km}$ and mean meridional radius was $60 \mathrm{~km}$. Therefore, the eddy impinged onto the shelf to some degree (at least at the surface). The mean traveling speed of the eddy over this period was $1.6 \mathrm{~km} \mathrm{~d}^{-1}\left(1.9 \mathrm{~cm} \mathrm{~s}^{-1}\right)$; however, it was nearly stagnant from 14 April to 15 June.

The model simulation gives the surface horizontal radius of the eddy between $49 \mathrm{~km}$ (in the along-shelf direction) and $67 \mathrm{~km}$ (in the cross-shelf direction) on 30 June (Figure 4b), in agreement with the satellite observations in terms of eddy's size. However, the eddy in the model displaced farther southwest along the shelf break (centered near $30.25^{\circ} \mathrm{E}, 43.37^{\circ} \mathrm{N}$ ).

Consistent with the observations, the model eddy was formed off the Crimean Peninsula in March and then migrated essentially along the same pathway as the observed eddy (Figure 4c, square). Similar to the observations, the larger part of the eddy remained outward of the shelf. From April on, the model eddy slowly moved to the southwest steered by the shelf slope, impinging onto the shelf most of the time unless occasionally 

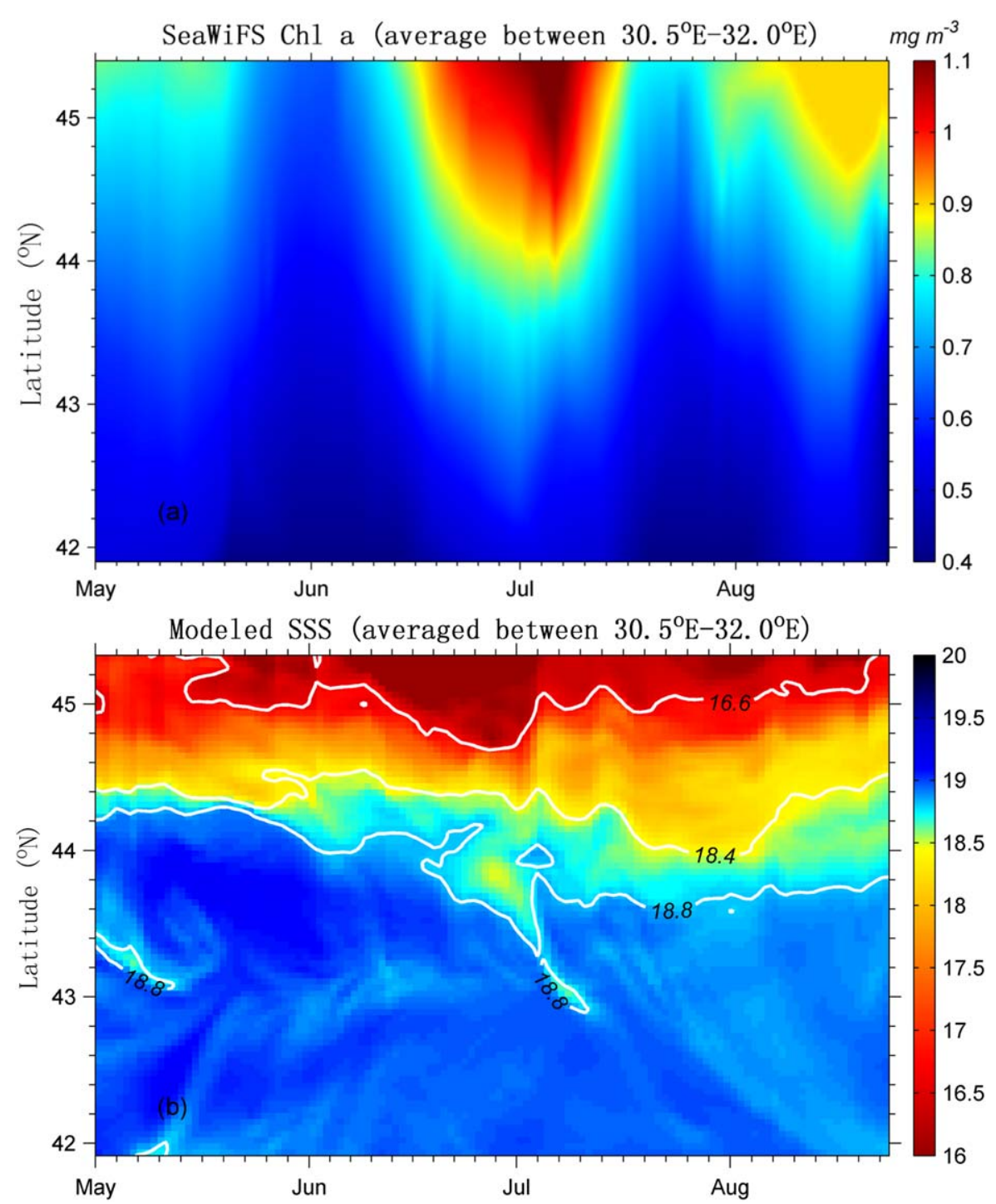

Figure 5. (top) Hovmöller diagram showing penetration of Chl-a from SeaWiFS (redrawn of Figure 3 in Shapiro et al. [2010]) from the NW shelf into the deep-sea region. The Chl- $a$ was averaged between $30.5^{\circ} \mathrm{E}$ and $32.0^{\circ} \mathrm{E}$. (bottom) Low surface salinity waters in the model, also averaged between $30.5^{\circ} \mathrm{E}$ and $32.0^{\circ} \mathrm{E}$.

pushed back by wind-driven offshore currents. The lifetime of this model anticyclonic eddy was more than three months, consistent with the eddy in the satellite observations in 2005, which is also close to that observed in 1998, but twice of that in 1993, as given by Ginzburg et al. [2002a, 2002b]. Comparison with satellite observations confirms that the model simulation captures the main features of the eddy in terms of horizontal dimensions, proportion of eddy impinging onto the shelf, the eddy's lifetime, and migration path and speed. Some disagreement (time/space lag) does not seem to affect significantly the estimates of the crossshelf transports integrated along the whole length of the "fence" or local transports around the eddy.

The impingement of anticyclonic eddies onto the shelf results in exchange between shelf and deep-sea waters and phytoplankton being carried from the productive shelf region to the deep-sea region. According to Shapiro et al. [2010], there were three events in 2005 when noticeable offshore spreading of shelf waters was seen in satellite-derived Chl- $a$ charts. These events occurred on 5-18 May, 7 June to 14 July, and 7-17 August, of which the second event is the most intense, as shown in the Hovmöller diagram [Hovmöller, 1949] in Figure $5 a$.

A persistent shelf-basin gradient is not only seen in Chl-a concentration (Figure 2), but also in sea surface salinity (SSS) (Figures 3c and 3d) due to significant inflows of the Danube, Dniester, and Dnieper rivers into 

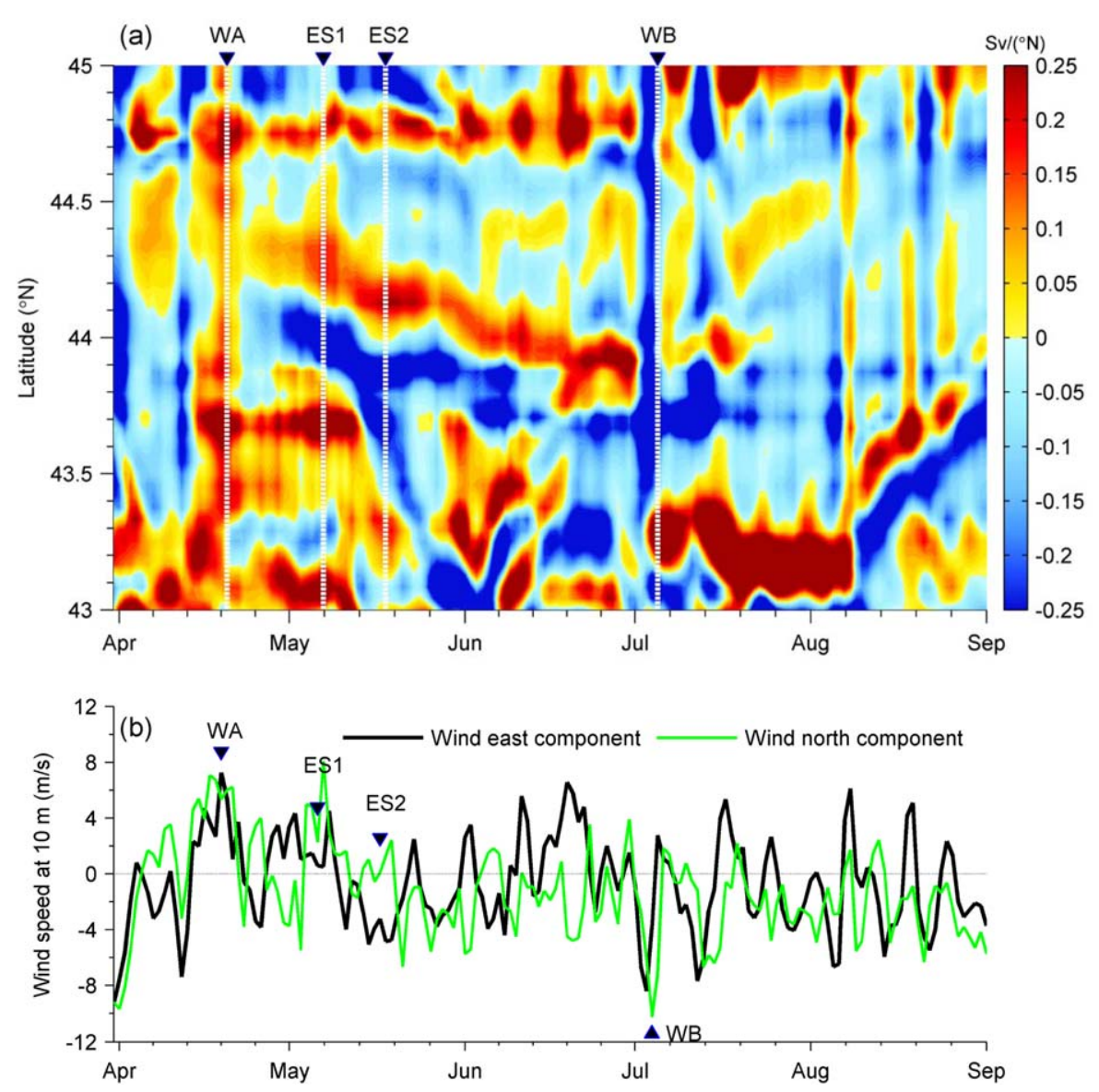

Figure 6. (a) Hovmöller diagram of the cross-shelf volume transport integrated from the sea surface to $20 \mathrm{~m}$ and calculated along the shelf edge as shown in Figure 1. The positive value is for offshore transport, and the units are Sv per $1^{\circ}$ latitude. (b) Wind components averaged west of $34^{\circ}$ E over the water for the same period as (Figure 6a). The events labeled as WA, ES1, ES2, and WB represent different mechanisms of cross-shelf exchange.

the NW shelf, making SSS another good tracer of the shelf waters. We use the SSS from the model to check whether these injections of shelf waters can be seen in the salinity field. The Hovmöller diagram in Figure $5 \mathrm{~b}$ is obtained by averaging SSS between $30.5^{\circ} \mathrm{E}$ and $32.0^{\circ} \mathrm{E}$ to be compatible with the Chl-a distribution in Figure 5a. It shows that at least the strongest injection (June-July) is clearly identifiable in the SSS field by the shape of the isolines between 16.6 and 18.8 .

\subsection{Volume Transport Across the Shelf Break}

Due to significant contrasts in $\mathrm{Chl}-a$ and other biochemical properties between the shelf waters and the Black Sea interior, we start our analysis with the euphotic layer of the sea. Figure 6a shows the Hovmöller diagram for daily volume transport between the shelf and the deep-sea region in the top $20 \mathrm{~m}$ of the water column. The data show depth integrated (0-20 m) daily offshore (red for positive value) and onshore (blue for negative value) transports along the shelf break between $43^{\circ} \mathrm{N}$ and $45^{\circ} \mathrm{N}$ for the period 1 April to 1 September 2005.

The diagram shows different patterns of the upper layer cross-shelf transport at multiple temporal scales, which are associated with various events. Some periods were characterized by prevailing offshore (positive) movement along the whole shelf break, for instance, during 15-22 April (hereafter referred to as Event WA, for wind event A). Other periods were dominated by overall onshore migration (negative), such as 1-4 July (Event WB, for wind event B). In the period between late April to the end of June, there were sections at the shelf break where the transport was offshore (Figure 6a, red bands) located next to the sections with the transport in the opposite direction (blue bands), the two timestamps during this event are labeled ES1 (for eddy event stage 1) and ES2 in Figure 6a. This "double-band" pattern was disrupted in early July but 
appeared again before decaying in mid-July. This pattern resembles the transports generated by an anticyclonic eddy partly impinging on the shelf.

The time series of wind speed averaged over the sea west of $34^{\circ} \mathrm{E}$ (Figure $6 \mathrm{~b}$ ) shows correlation with the volume transport diagram in Figure 6a. During strong positive events (offshore transports, red vertical columns in Figure 6a, related to upwelling of coastal waters), the NW shelf was influenced by southwesterly wind and hence the Ekman drift was toward southeast, while the northeasterly wind was prevailing during negative events (onshore transports, related to downwelling of coastal waters). During the eddy-dominated event (late April to the end of June), the wind was weak, and both wind speed and direction were highly variable.

The offshore and onshore volume transports (denoted VT) are calculated using the equation:

$$
\begin{aligned}
& V T_{z 1, z 2}^{\text {offshore }}(t)=\int_{\text {start }}^{\text {end }} \int_{z 1}^{z 2}(\boldsymbol{u} \cdot \boldsymbol{n}) d z d l \quad \text { when }(\boldsymbol{u} \cdot \boldsymbol{n})>0 \\
& V T_{z 1, z 2}^{\text {onshore }}(t)=\int_{\text {start }}^{\text {end }} \int_{z 1}^{z 2}(\boldsymbol{u} \cdot \boldsymbol{n}) d z d l \quad \text { when }(\boldsymbol{u} \cdot \boldsymbol{n})<0
\end{aligned}
$$

where $V T_{z 1, z 2}^{\text {onshore }}(t)$ and similar $V T_{z 1, z 2}^{\text {offshore }}(t)$ are the volume onshore and offshore transports, respectively, at a particular time $t$ integrated across the section of the shelf boundary between the start and end points on the boundary and between the depth levels $z 1$ and $z 2 ; \boldsymbol{u}=\boldsymbol{u}(t, z, I)$ is the horizontal velocity vector at the boundary; $\boldsymbol{n}$ is the unit vector directed toward the deep-sea region and normal to the shelf boundary; $z$ is depth; / is the length along the shelf boundary. Positive value denotes offshore transport, and negative onshore transport. For analysis of eddy-induced transports, the start and end points confine the section of the shelf break influenced by the eddy, and their locations were calculated daily as the eddy moved southwestward. For all other analyses, the start and end points are the ends of the shelf boundary located at the coast as shown in Figure 1.

The two main wind events (WA and WB) and the eddy-dominated event (late April to the end of June) are analyzed in more detail in the subsequent subsections.

\subsubsection{Wind-Induced Surface Offshore Transport (Event WA)}

Event WA (15-22 April) was characterized by prevailing southwesterly wind and offshore water movements over the shelf break in the top $20 \mathrm{~m}$. The wind amplitude peaked on 19 April with the spatial mean $9 \mathrm{~m} \mathrm{~s}^{-1}$ over the sea west of $34^{\circ} \mathrm{E}$ (Figure 7a), which was almost twice the spring-summer mean value. Due to the Ekman effect, the wind-generated surface flow in the offshore direction was particularly strong over the inner and middle shelves. Over the outer shelf, the offshore surface flow decreased; however, it still dominated the currents at the shelf break. At the surface, a circular anticyclonic eddy, centered near $31.5^{\circ} \mathrm{E}$, $44.0^{\circ} \mathrm{N}$ with a radius of $55 \mathrm{~km}$, could be seen from the current field just outside the NW shelf (Figure $7 \mathrm{~b}$ ). Its maximum orbital velocity was about $25 \mathrm{~cm} \mathrm{~s}^{-1}$, but it did not impinge onto the shelf.

The Ekman effect decreased quickly in the vertical, and its influence was confined to the upper $20 \mathrm{~m}$ in this study. Below the $20 \mathrm{~m}$ depth, the eddy showed a partial penetration onto the shelf especially at $75 \mathrm{~m}$ (Figure 7c) which is seen in the meridional velocity transect along $44.29^{\circ} \mathrm{N}$ (Figure $7 \mathrm{~d}$ ). This peripheral part of the eddy contributed to the generation of the northward-flowing (onshore, negative) current below the surface Ekman layer between $44^{\circ} \mathrm{N}$ and $44^{\circ} 15^{\prime} \mathrm{N}$ and eastward (offshore, positive) current between $44^{\circ} 20^{\prime} \mathrm{N}$ and $44^{\circ} 30^{\prime} \mathrm{N}$. In other words, the upper part of the eddy was squeezed and pushed away from the shelf break (indicated by blue squares in Figures $7 \mathrm{~b}$ and 7c) by the offshore Ekman flow (Figure 7d), but the eddy still contributed to cross-shelf transport at depth.

The pattern of the combined action of wind-driven current in the surface layer and eddy-generated transport below the Ekman layer can be seen in the profile of volume fluxes along the shelf break (Figure 7e), plotted along the section of the shelf break shown in Figure 4c, i.e., excluding the short connecting lines between the shelf break and the coast. The upper layer above $20 \mathrm{~m}$ was dominated by the offshore flux induced by southwesterly wind over the whole shelf. 


\section{QAGU Journal of Geophysical Research: Oceans}
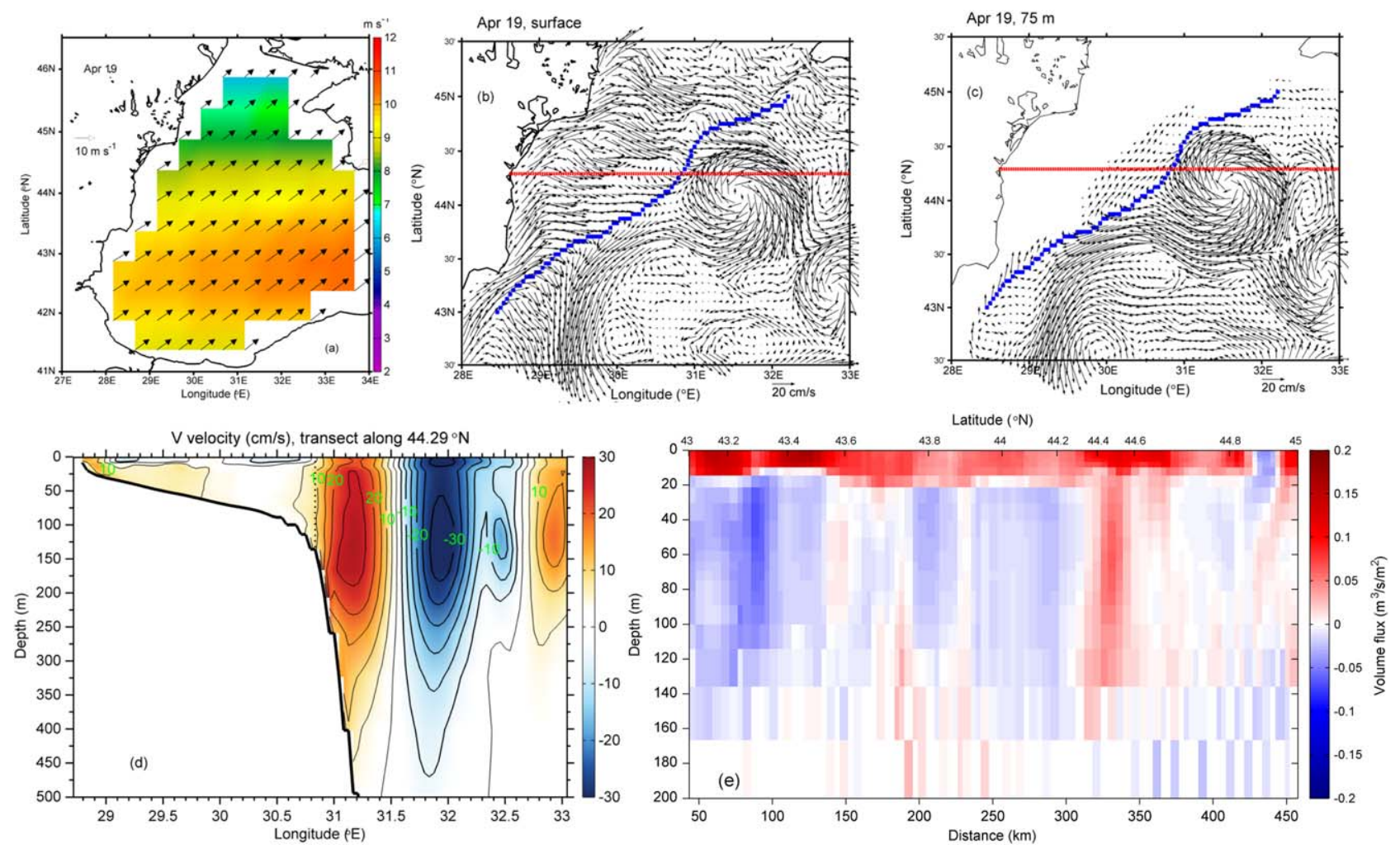

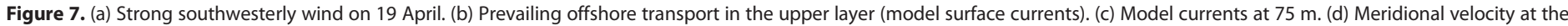
transect along $44.29^{\circ} \mathrm{N}$ indicated by the red dotted line in Figures $7 \mathrm{~b}$ and $7 \mathrm{c}$. (e) Volume flux across the shelf break indicated by the blue squares in Figures $7 \mathrm{~b}$ and $7 \mathrm{c}$. In this case, the

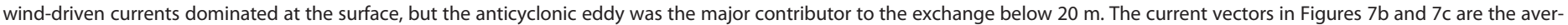
age of four neighboring grid points.

The offshore transport calculated along the enclosed shelf boundary above $20 \mathrm{~m}$ was $0.32 \mathrm{~Sv}$ while the onshore transport (mainly between $44.85^{\circ} \mathrm{N}$ and $44.9^{\circ} \mathrm{N}$ ) was significantly smaller. Below $20 \mathrm{~m}$, the crossshelf transport was driven by a cyclonic meander of the Rim Current with an associated small anticyclonic eddy $\left(43^{\circ} \mathrm{N}-43.5^{\circ} \mathrm{N}\right)$ and the large anticyclonic Sevastopol Eddy $\left(43.9^{\circ} \mathrm{N}-44.6^{\circ} \mathrm{N}\right)$. The onshore branch of the Sevastopol Eddy below $20 \mathrm{~m}$ is fairly diffused and located between $43.9^{\circ} \mathrm{N}$ and $44.3^{\circ} \mathrm{N}$, whilst its offshore branch is narrow and intense $\left(44.4^{\circ} \mathrm{N}-44.6^{\circ} \mathrm{N}\right)$. This pattern is consistent with the existence of a filament of Chl- $a$ enriched waters identified by Shapiro et al. [2010] from remotely sensed data. In the layer below $20 \mathrm{~m}$, both the offshore $(0.63 \mathrm{~Sv})$ and onshore $(-0.93 \mathrm{~Sv})$ transports were higher due to action of the eddy and meander, than that in the upper layer directly affected by the Ekman drift. The overall water balance on the shelf was ensured by the river runoff, and precipitation minus evaporation.

It can been seen in Figures 7c and 7d that below the Ekman depth, the Sevastopol Eddy was interacting with a smaller cyclonic eddy to the east and an anticyclonic eddy to the southeast that both contributed to its nonaxisymmetric shape. The theory of one circular eddy stretched by nearby eddies was developed by McWilliams [1984].

\subsubsection{Eddy-Induced Transport, Stage One (ES1)}

The Hovmöller diagram in Figure 6a shows the existence of an eddy-like pattern from 23 April to 30 June when strong localized offshore motion (red band) was accompanied by onshore transport (blue band). The structure, associated with the Sevastopol Eddy, moves gradually to the south. At the initial stage of the eddy migration (23 April to 10 May), the onshore transport was represented by a single blue band, which subsequently splits into two branches. In this subsection, we analyze the first stage using a snapshot on 6 May 2005, hereafter called event ES1. On that day, the southwesterly wind had relaxed over the NW shelf 


\section{QAGU Journal of Geophysical Research: Oceans}
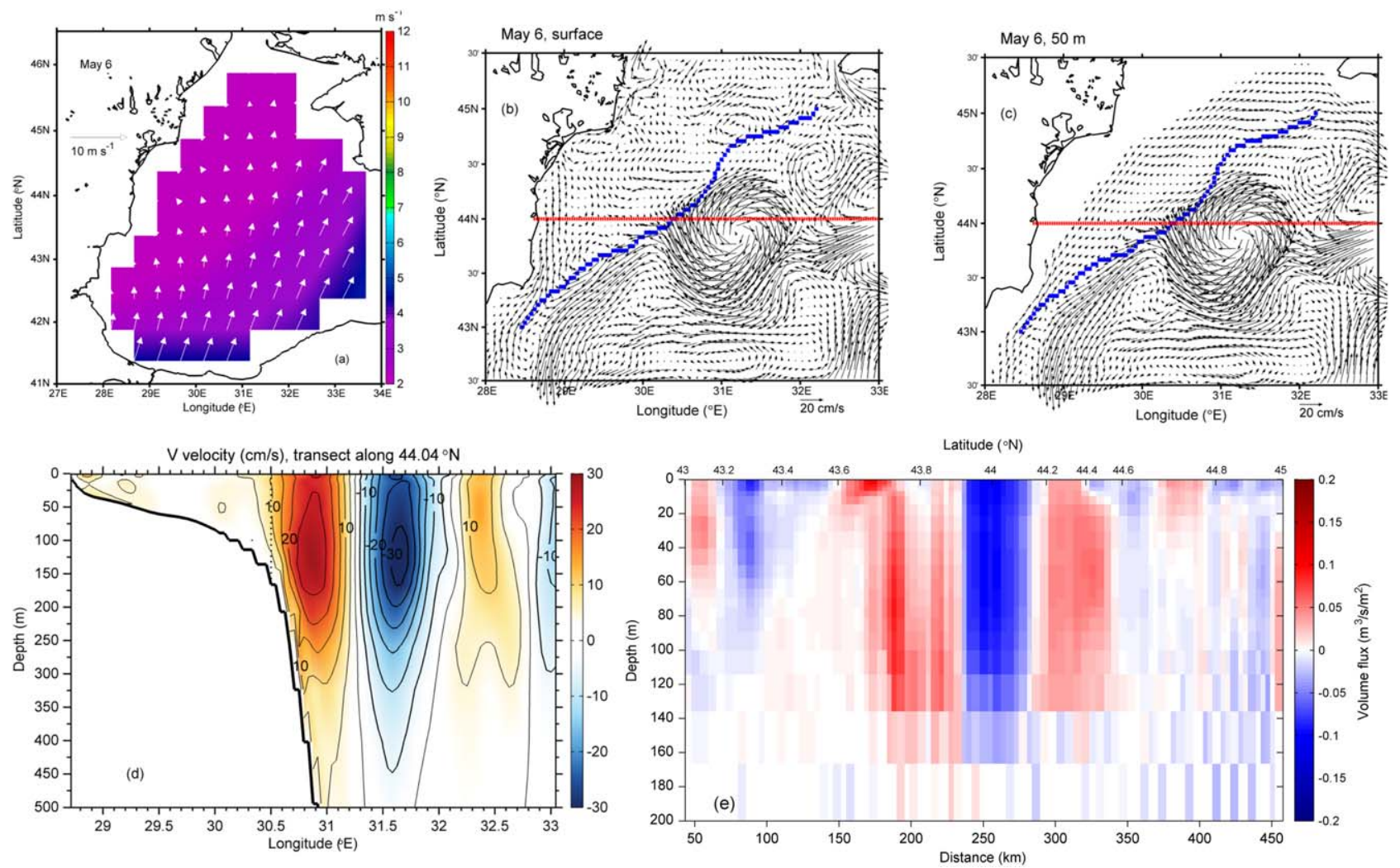

Figure 8. (a) NCEP wind field. (b) Model surface currents. (c) Model currents at $50 \mathrm{~m}$. (d) Meridional velocity at the zonal cross section along $44.04^{\circ} \mathrm{N}$ indicated by the red dotted line in Figures $8 \mathrm{~b}$ and $8 \mathrm{c}$. (e) Volume flux across the shelf break. In this case, the wind was weak on 6 May; the cross-shelf transport was associated with an anticyclonic eddy seen in both Figures $8 \mathrm{~b}$ and $8 \mathrm{c}$.

and adjacent regions of the deep sea, reaching only $2 \mathrm{~m} \mathrm{~s}^{-1}$ on average (Figures $6 \mathrm{~b}$ and $8 \mathrm{a}$ ), hence making Ekman transport a less important contributor to the exchange.

At the surface, the Sevastopol Eddy had an orbital velocity exceeding $30 \mathrm{~cm} \mathrm{~s}^{-1}$ (Figure 8a). Its penetration onto the shelf was significantly stronger than during wind event WA, and mainly occurred between $43.8^{\circ} \mathrm{N}$ and $44.5^{\circ} \mathrm{N}$ (Figure $8 \mathrm{~b}$ ). The maximum northward component of the current at the shelf break reached 10 $\mathrm{cm} \mathrm{s}^{-1}$, thus facilitating the onshore cross-shelf transport (Figure 8d). In contrast to event WA, the vertical axis of the eddy during ES1 was not inclined, and the eddy had its largest horizontal extension at the surface, see the meridional velocity transect along $44.04^{\circ} \mathrm{N}$ in Figure $8 \mathrm{~d}$. The eddy induced significant crossshelf transport both onshore and offshore over the entire water column, as shown in Figure 8e. The eddyinduced offshore transport was about $0.31 \mathrm{~Sv}$ and was essentially homogeneous from surface to the seabed, accounting for $24 \%$ of the overall offshore cross-shelf transport at that day. The eddy-induced onshore transport was $-0.51 \mathrm{~Sv}$, larger than the eddy's offshore contribution. This was due to a combined action of the Sevastopol Eddy and the adjacent meander of the Rim Current southwest of the eddy (Figures $8 \mathrm{~b}$ and $8 \mathrm{c}$ ). The offshore transport southwest of the eddy (Figure $8 \mathrm{e}$, red band, between $43.6^{\circ} \mathrm{N}$ and $43.9^{\circ} \mathrm{N}$ ) was also due to the meandering Rim Current.

\subsubsection{Anticyclonic Eddy Enhanced by a Cyclonic Meander (ES2)}

The Hovmöller diagram in Figure 6a shows that after 10 May the blue band representing the offshore transport by the eddy splits and forms a "two-leg" structure, suggesting that an additional factor, apart from the Sevastopol Eddy, contributed to the offshore transport. Next, we analyze the snapshot taken on 17 May (Event ES2).

The wind on 17 May was blowing from the east, with a spatial mean amplitude of only $3.6 \mathrm{~m} \mathrm{~s}^{-1}$ (Figure 9a), similar to Event ES1. The wind was too weak to generate a conspicuous Ekman drift. By 17 May, the 


\section{QAGU Journal of Geophysical Research: Oceans}
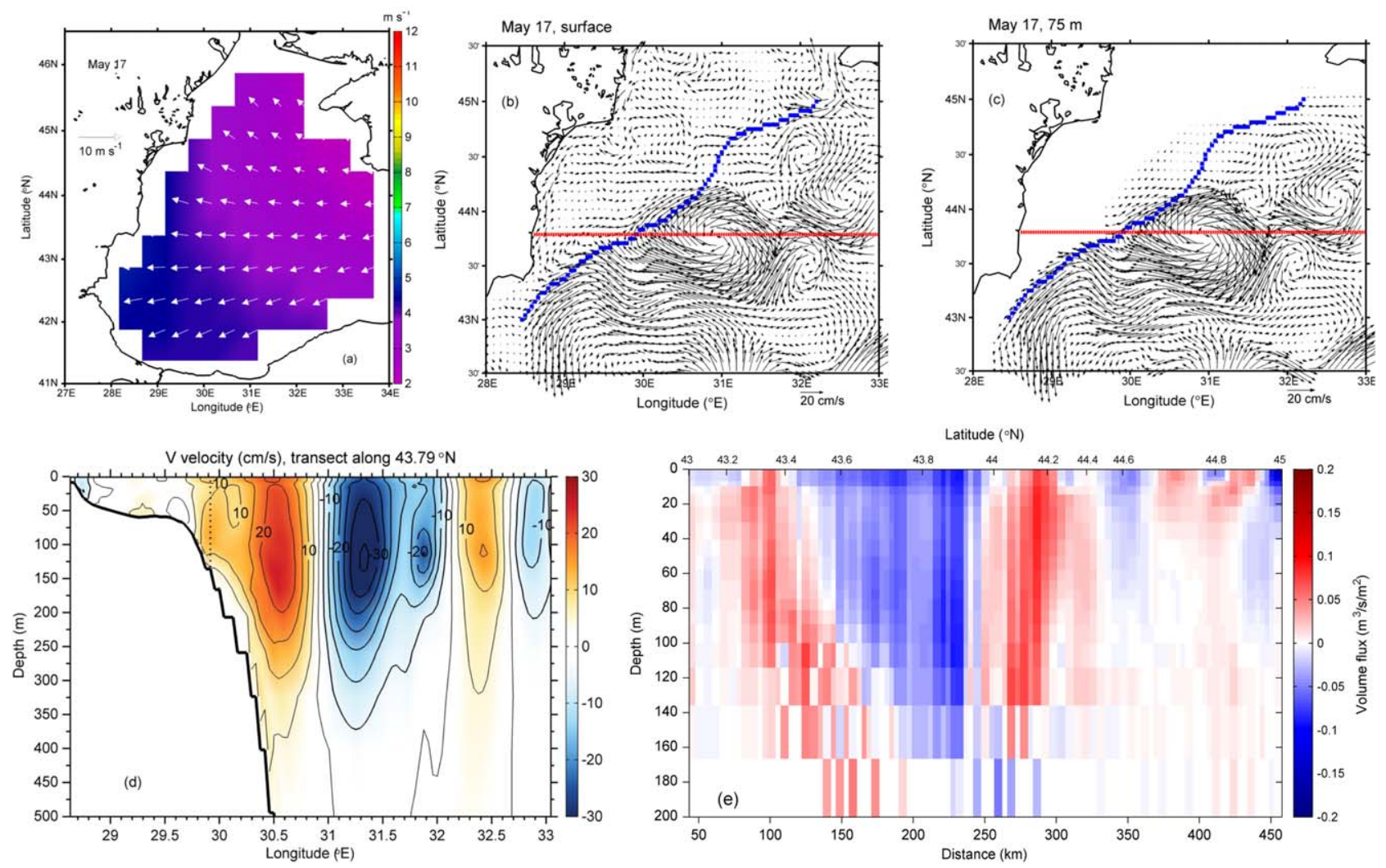

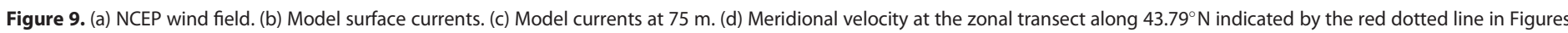

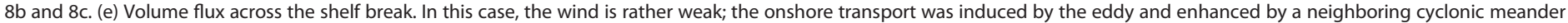
of the Rim Current south of the eddy on 17 May.

Sevastopol Eddy, after a slow propagation in the southwest direction, approached an intense cyclonic meander of the Rim Current (Figures 9b and 9c). The eddy was elongated in the northwest-southeast direction, which facilitated a greater penetration onto the shelf, with farther penetration at the surface than at depth (Figures 9b-9d). The eddy was particularly enhanced at its eastern and southern edges by the cyclonic meander. Using a threshold value of $5 \mathrm{~cm} \mathrm{~s}^{-1}$ of orbital velocity as the eddy's boundary, one can see that the east-west semiaxis of the eddy enlarged from $40 \mathrm{~km}$ on 19 April to $56 \mathrm{~km}$ on 6 May to $72 \mathrm{~km}$ on 17 May. On 17 May, the eddy-induced offshore transport was $0.72 \mathrm{~Sv}$ and the onshore transport was $-0.50 \mathrm{~Sv}$, accounting for $52 \%$ and $35 \%$ of the overall onshore and offshore transports, respectively. In addition, the meander itself made a considerable contribution to the cross-shelf exchange, which was shown by a large and diffused blue band between $43.6^{\circ} \mathrm{N}$ and $43.75^{\circ} \mathrm{N}$ in Figure $9 \mathrm{e}$.

\subsubsection{Wind-Induced Surface Onshore Transport (Event WB)}

As shown by the Hovmöller diagram in Figure 6a, the near-surface cross-shelf transport during Event WB (1-4 July) was directed onshore and opposite to that of Event WA, and was associated with the downwelling of coastal waters. The wind was northeasterly and stronger than on 19 April, with the maximum amplitude averaged over the sea west of $34^{\circ} \mathrm{E}$ reaching $11 \mathrm{~m} \mathrm{~s}^{-1}$ on 4 July (Figure 10a), generating a significant onshore surface Ekman transport across the shelf break and a southward coastal jet of $10-80 \mathrm{~cm} \mathrm{~s}^{-1}$ and (Figure 10b). The strong Ekman drift nearly masked the surface signature of the Sevastopol Eddy (Figure 10b). The onshore transport in the top $20 \mathrm{~m}$ was $-0.55 \mathrm{~Sv}$ on average over 4 days, and occupied nearly all the section of the shelf break with the only exception of a small area near Cape Kaliakra (see Figure 1), where the strong coastal flow crossed the shelf break generating some offshore transport.

Below the upper Ekman layer, the anticyclonic eddy was clearly identifiable with its center near $43.40^{\circ} \mathrm{N}$, $30.5^{\circ} \mathrm{E}$, (Figure $10 \mathrm{c}$ ), which was significantly deformed by the Rim Current meanders both southwest and 


\section{QAGU Journal of Geophysical Research: Oceans}
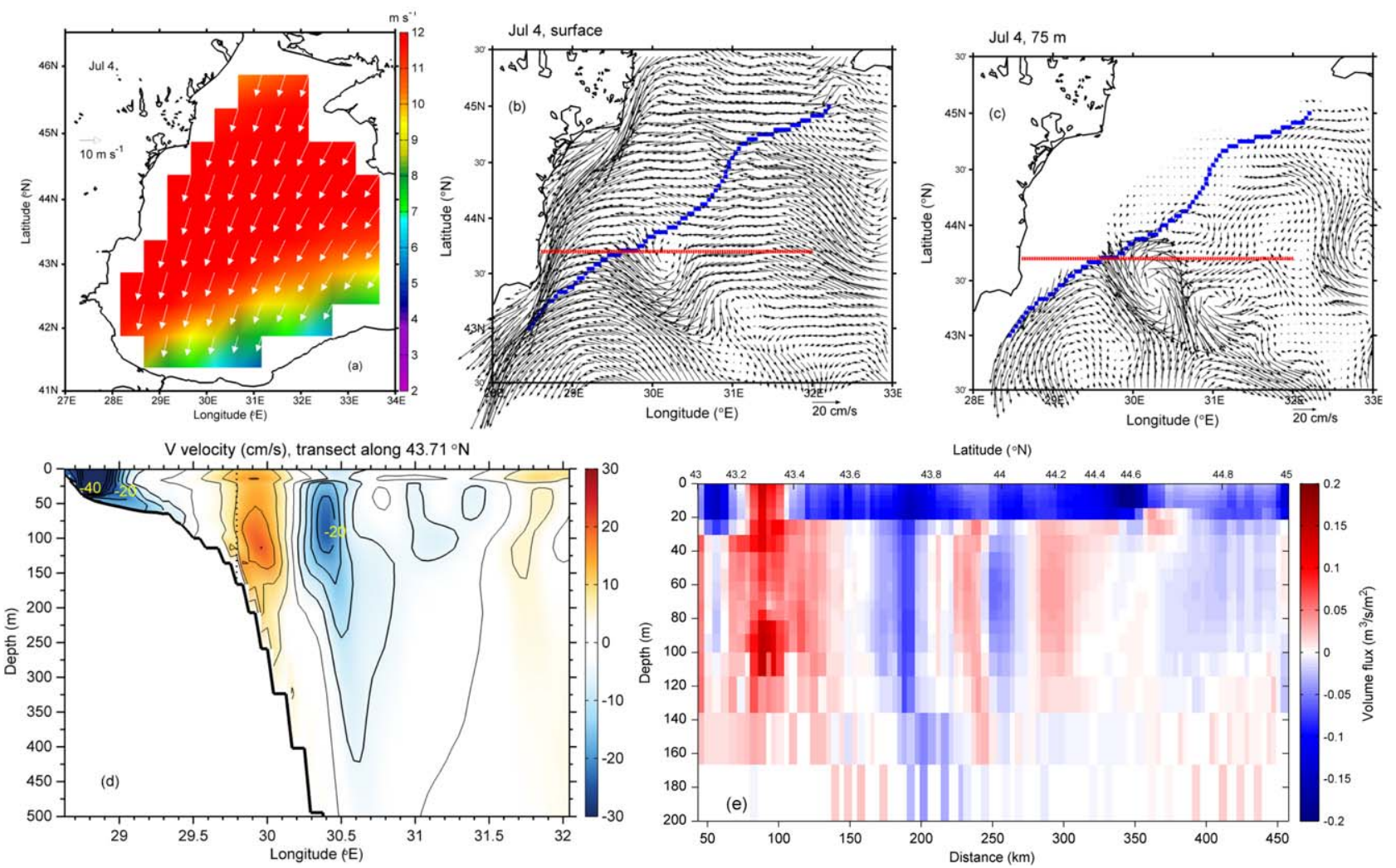

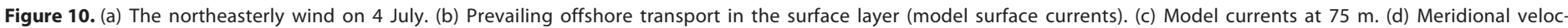

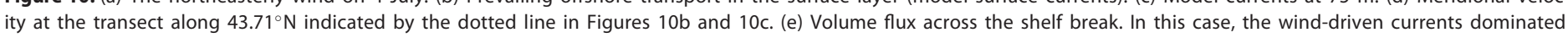
at the surface, but the anticyclonic eddy is the major contributor to the exchange below $20 \mathrm{~m}$.

northeast of the eddy. The eddy in this location is often called the Kaliakra Eddy [Oguz et al., 1993]; however, we can see that it is the displaced Sevastopol Eddy, which has traveled along the shelf break from southwest of the Crimea Peninsula.

The effect of the Ekman drift resulted in the top part of the eddy being twisted as its southwest portion (onshore) is enhanced while the northeast portion (offshore) is suppressed. The transect of the meridional velocity along $43.71^{\circ} \mathrm{N}$ (Figure 10) shows that the top part of the eddy was displaced onto the shelf (Figure 10d) while the highest orbital velocity was achieved below the Ekman layer at depth from 75 to $150 \mathrm{~m}$. The horizontal extension of the eddy was smaller than that during Events WA, ES1, and ES2; however, its maximum orbital velocity, achieved at $100 \mathrm{~m}$, increased to $45 \mathrm{~cm} \mathrm{~s}^{-1}$ at its southwest portion. The eddy contributed $-0.35 \mathrm{~Sv}$ to the onshore flux, but it has to be noted that a significant part of it was in the upper layer where the effects of the eddy and the strong wind were combined (Figure 10e). The offshore transport was generated by the eddy only below the top $20 \mathrm{~m}$ at the rate of $0.24 \mathrm{~Sv}$. The meander of the Rim Current northeast of the eddy was relatively weak, while the meander southwest of the eddy was enhanced leading to significant offshore transport (Figure 10c).

The transports associated with wind and eddy events and averaged over the respective periods are summarized in the Table 1. The numbers in the brackets show the total volume (in units of $10^{12} \mathrm{~m}^{3}$ ) of water transported across the shelf break over the corresponding time period.

In order to assess the sensitivity of the cross-shelf break transports to the exact location of the "fence," the computations were also performed for the "fences" located at 170 and $230 \mathrm{~m}$ depth contours. The results are very close due to the steep continental slope, where the horizontal separation between 170, 200, and $230 \mathrm{~m}$ isobaths is very small, and hence the "fence" crossed mainly the same model grid boxes.

\subsection{Maintenance of the Shelf Break Front}

Due to the gradient in salinity and temperature between the shelf and the deep-sea region, the currents crossing the shelf break contribute to the transport of salt and heat on and off the shelf. 


\section{QAGU Journal of Geophysical Research: Oceans}

Table 1. Average Offshore and Onshore Cross Fence (Shelf Break Plus the Two Segments Connected With the Coast) Transports (in Sv) and Associated Volumes of Transferred Waters $\left(10^{12} \mathrm{~m}^{3}\right.$, in Brackets) for the Three Events in Spring-Summer 2005 Compared to the Entire Study Period

\begin{tabular}{|c|c|c|c|c|}
\hline & Event WA 15-22 Apr & Eddy $23 \mathrm{Apr}$ to 30 Jun & Event WB 1-4 Jul & Whole Period 1 Apr to 31 Aug \\
\hline$V T_{0.20}^{\text {offshore }}$ & $0.32(0.22)$ & $0.06(0.35)$ & $0.19(0.07)$ & $0.237(3.13)$ \\
\hline$V T_{0,20}^{\text {onshore }}$ & $-0.13(-0.09)$ & $-0.05(-0.31)$ & $-0.55(-0.19)$ & $-0.243(-3.21)$ \\
\hline$V T_{0, \text { bottom }}^{\text {offshore }}$ & $0.95(0.66)$ & $0.48(2.84)$ & $1.28(0.44)$ & $1.14(15.1)$ \\
\hline$V T_{0, \text { bottom }}^{\text {onshore }}$ & $-1.06(-0.73)$ & $-0.40(-2.41)$ & $-1.33(-0.46)$ & $-1.18(15.6)$ \\
\hline
\end{tabular}

The instantaneous transports of salt and heat in the top $20 \mathrm{~m}$ across the shelf break were calculated using the equations:

$$
\begin{gathered}
S T_{0,20}(t)=\int_{\text {start }}^{\text {end }} \int_{0}^{20} S \rho(\boldsymbol{u} \cdot \boldsymbol{n}) d z d l \\
H T_{0,20}(t)=\int_{\text {start }}^{20} \int_{0}^{20} C_{p} \rho T(\boldsymbol{u} \cdot \boldsymbol{n}) d z d l
\end{gathered}
$$

where $S T_{0,20}(t)\left(\mathrm{kg} \mathrm{s}^{-1}\right)$ is the salt transport in the top $20 \mathrm{~m}, S$ (psu) is the salinity of water flowing in or out the shelf, $\rho\left(\mathrm{kg} \mathrm{m}^{-3}\right)$ is the density of water, $H T_{0,20}(t)\left(\mathrm{J} \mathrm{s}^{-1}\right)$ is the heat transport in the top $20 \mathrm{~m}, C_{p}=4.0$ $\times 10^{3} \mathrm{~J} \mathrm{~kg}^{-1} \mathrm{~K}^{-1}$ is the specific heat capacity of seawater; start and end represent the coastal endpoints of the shelf boundary. Similar equations are used for other depth ranges.

The amounts of salt and heat crossing the shelf break during the Events WA (15-22 April), WB (1-4 July), and by the eddy action ( 23 April to 30 June) are shown in Table 2. The values corresponding to the wind events were calculated along the whole section of the "fence" shown in Figure 1, while the values related to the eddy action were calculated only for a segment of the shelf break influenced by the eddy. The location of this segment changed with time as the eddy migrated southwestward. The heat and salt transports contribute to the variation of density of the shelf waters and hence to the density gradient across the shelf break and the maintenance of the density front along the shelf break. In order to calculate the "exchange transports," let us apply the equations similar to those used in turbulence theory to assess, say turbulent viscosity and diffusivity. At any moment in time let us split cross-shelf velocity, temperature, salinity, and density into the mean values, i.e., averaged along the length and the depth of the "fence," and their fluctuations about the mean:

$$
\begin{aligned}
& S=S_{0}(t)+S^{\prime}(t, l, z) \\
& T=T_{0}(t)+T^{\prime}(t, l, z) \\
& \rho=\rho_{0}(t)+\rho^{\prime}(t, l, z) \\
& \boldsymbol{u}=\boldsymbol{u}_{0}(t)+\boldsymbol{u}^{\prime}(t, l, z)
\end{aligned}
$$

\begin{tabular}{|c|c|c|c|}
\hline & $\begin{array}{l}\text { Event WA } \\
\text { 15-22 Apr }\end{array}$ & $\begin{array}{c}\text { Eddy } 23 \mathrm{Apr} \\
\text { to } 30 \text { Jun }\end{array}$ & $\begin{array}{l}\text { Event } \\
\text { WB 1-4 Jul }\end{array}$ \\
\hline$H T_{0,20}$ & $\frac{8.04}{-3.38}$ & $\frac{16.82+6.39=23.2}{-3.20-16.04=-19.2}$ & $\frac{5.53}{-16.2}$ \\
\hline$H T_{0, \text { bottom }}$ & $\frac{22.6}{-24.7}$ & $\frac{71.09+42.19=113.3}{-17.81-76.53=-94.3}$ & $\frac{20.7}{-26.5}$ \\
\hline$S T_{0,20}$ & $\frac{4.01}{-1.73}$ & $\frac{4.76+1.82=6.58}{-0.88-5.07=-5.95}$ & $\frac{1.23}{-3.55}$ \\
\hline$S T_{0, \text { bottom }}$ & $\frac{12.7}{-14.4}$ & $\frac{33.95+22.06=56.0}{-8.77-39.09=-47.9}$ & $\frac{8.67}{-8.92}$ \\
\hline
\end{tabular}

where the subscript zero indicates the mean value calculated as follows for salt:

$$
S_{0}(t)=\frac{\int_{\text {bottom }}^{\text {surface }} \int_{\text {start }}^{\text {end }} S(I, z, t) d l d z}{\int_{\text {bottom }}^{\text {surface }} \int_{\text {start }}^{\text {end }} d l d z}
$$

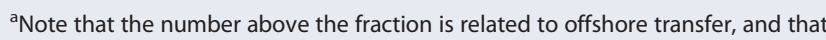
and similar for other variables. 
The mass flux, MF (i.e., transport through a $1 \mathrm{~m}^{2}$ area) is:

$$
M F(t, l, z)=\rho(t, l, z) * u(t, l, z)=\rho_{0} u_{0}+\rho_{0} u^{\prime}+\rho^{\prime} u_{0}+\rho^{\prime} u^{\prime}
$$

and the mass transport, $M T$, equals to the mass flux integrated over the entire "fence" as follows:

$$
\begin{gathered}
M T(t)=\int_{\text {bottom start }}^{\text {surface end }} \int_{\text {sto }}^{\text {surface end }} \rho(t, I, z) *(u(I, z, t) \cdot n) d l d z= \\
\rho_{0} u_{0} * A+\int_{\text {bottom start }}^{\text {sut }} \rho^{\prime}(t, I, z) *\left(u^{\prime}(I, z, t) \cdot n\right) d l d z
\end{gathered}
$$

where $A$ is the area of the "fence" (depth $\times$ length), and the average of the fluctuations is equal to zero by design.

In this section, we are only interested in the "turbulent" component of the mass flux (second term on the right-hand side in equation (7)), generated by the nonlinear term $\rho^{\prime} \times u^{\prime}$. This term controls the dissolution of the front, not the mean advection of the front, i.e., the first term on the right-hand side in equation (7). Hereafter, we call this "turbulent" component the "exchange transport," as it is physically associated with swapping of water parcels of identical volume between the shelf and the deep-sea region.

As variations in temperature and salinity along the "fence" are relatively small, we can use the linearized equation of state to link salinity/heat transports with the mass transport across the shelf break and split the mass transport exchange into two components—related to the salt $\left(E X M_{S}\right)$ and heat $\left(E X M_{T}\right)$ transports, respectively:

$$
\begin{gathered}
\operatorname{EXM}_{S}(t)=\rho_{0}(t) \int_{\text {bottom start }}^{\text {surface end }} \int_{\text {stor }}^{\text {end }} \beta(t, l, z) * S^{\prime}(t, I, z) *\left(\boldsymbol{u}^{\prime}(I, z, t) \cdot \boldsymbol{n}\right) d l d z \\
\operatorname{EXM}_{T}(t)=-\rho_{0}(t) \int_{\text {bottom start }}^{\text {surface end }} \int^{\text {end }} \alpha(t, l, z) * T^{\prime}(t, I, z) *\left(\boldsymbol{u}^{\prime}(I, z, t) \cdot \boldsymbol{n}\right) d l d z
\end{gathered}
$$

Based on the mass conservation, a corresponding gain of mass $(\Delta M)$ and change of average density $(\Delta \rho)$ of shelf waters due to salt and heat exchanges can be calculated using the following equations and corresponding integrals for average density:

$$
\begin{aligned}
& \Delta M_{S}=-\int_{1}^{31} \int_{\text {April }}^{\text {August }} \operatorname{EXM}_{S}(t) d t \\
& \Delta M_{T}=-\int_{1}^{31} \int_{\text {April }}^{\text {August }} \operatorname{EXM}_{T}(t) d t
\end{aligned}
$$

As we can see from Table 3, the exchanges of saline and warmer deep-sea waters with fresher and colder shelf waters result in an overall increase in average shelf water density $\left(+0.51 \mathrm{~kg} \mathrm{~m}^{-3}\right)$, and hence reduction in the density contrast between the shelf and deep sea. This change is the sum of density increase due to salt exchange $\left(+0.67 \mathrm{~kg} \mathrm{~m}^{-3}\right)$ and a density decrease due to heat exchange $\left(-0.16 \mathrm{~kg} \mathrm{~m}^{-3}\right)$. In other words, while the salt exchanges smooth out the density contrast, the heat exchanges enhance the density gradient and contribute to the maintenance of the density front along the shelf break. 


\section{Discussion}

The cross-shelf filaments, mesoscale eddies, and meanders of the Rim Current have long been considered an important mechanism for the cross-shelf break exchange in the Black Sea [Sur et al., 1996; Zatsepin et al., 2003]. However, quantitative estimates have been few [see Shapiro et al., 2010]. In this paper, we use a 3-D high-resolution ocean model to provide a quantitative estimate of cross-shelf break transports in the NW Black Sea with a focus on the quantification of two exchange mechanisms, one related to Ekman drift in the surface layer and the other one related to a slowly moving long-lived anticyclonic eddy and associated meanders of the Rim Current.

The two mechanisms are different not only in terms of underlying physics (frictional effects in the Ekman flows versus quasi-geostrophic flows in the eddy/meanders) but also in terms of their geometric patterns. Ekman drift causes nearly uniform onshore or offshore flow along a large section of the shelf break, but it is confined to only the top layer of approximately $20 \mathrm{~m}$. Eddies and meanders penetrate toward the bottom at the shelf break, but they are restricted laterally by the size of the eddy or meander.

The strong wind-driven currents occurred during Event WA (15-22 April 2005) generated a net offshore near-surface transport of $0.19 \mathrm{~Sv}$ (which was the balance of $0.32 \mathrm{~Sv}$ offshore and $-0.13 \mathrm{~Sv}$ onshore transports; see Table 1), corresponding to the upwelling of coastal waters and a compensating onshore flow below the Ekman depth. During this event, $0.66 \times 10^{12} \mathrm{~m}^{3}$ of shelf water was transported into the deep-sea region when at all depth levels were combined, which is approximately equal to $23 \%$ of the overall volume of the shelf waters $\left(2.78 \times 10^{12} \mathrm{~m}^{3}\right.$; see Figures 11a-11c).

The second wind event WB (1-4 July 2005) featured higher wind speeds up to $11 \mathrm{~m} \mathrm{~s}^{-1}$ and generated a net onshore near-surface transport of $-0.36 \mathrm{~Sv}$. During this event, the total amount of $0.46 \times 10^{12} \mathrm{~m}^{3}$ (at all depths) of deep sea waters entered the shelf, which equates to $17 \%$ of the overall shelf water volume. $\mathrm{A}$ similar amount moved in the opposite direction.

Strong wind events in the spring-summer-early autumn period are rare and normally do not last more than 1 week. Apart from these significant events, the contribution of wind-driven current to the cross-shelf break transport was small.

Both upwelling and downwelling wind events replaced surface waters with subsurface (below Ekman depth) ones, which are different not only by their physical but also by biochemical properties. However, the analysis of the latter is beyond the scope of this paper.

The eddy-induced exchange is different from that induced by the Ekman drift, as the eddy mainly replaces surface water and subsurface water with the same layer water, and hence contributes to the selfcleaning of eutrophied surface shelf waters with oligotrophic surface waters of the deep-sea region.

Despite occupying a smaller area, the eddy acts as a cross-boundary agent for a relatively long time scalein 2005 the eddy-induced transport is clearly detectable from 23 April to 30 June (see Figure 6a). Below the Ekman depth, the eddy-induced transport is detectable even during strong wind events (see Figures 7e and 10e).

During the 69 days from 23 April to 30 June 2005, the anticyclonic Sevastopol Eddy transferred shelf water offshore across the shelf break at an average rate of $0.48 \mathrm{~Sv}$, with a total volume of $2.84 \times 10^{12} \mathrm{~m}^{3}$, which is comparable with the total volume of the shelf waters over the NW shelf of $2.78 \times 10^{12} \mathrm{~m}^{3}$. The offshore (onshore) transport confined within the top $100 \mathrm{~m}$ was on average $0.32 \mathrm{~Sv}(-0.28 \mathrm{~Sv})$. This estimate, which is based on the model simulations, is close with that obtained from observations, namely, 0.3 Sv for the offshore transport by the eddy in the top $100 \mathrm{~m}$ [Shapiro et al., 2010]. The total volume of water transported out of the shelf in the top $100 \mathrm{~m}$ estimated from observations was quoted as $1 \times 10^{12} \mathrm{~m}^{3}$, similar to the figure of $1.1 \times 10^{12} \mathrm{~m}^{3}$ obtained here from the model simulation. The long-term net transport induced by the eddy is small as the onshore and offshore-components nearly balance each other. However, it is important to quantify in and out-fluxes separately, as they move different waters, as can be seen from the fact that even though the net volumetric transport is close to zero, the net heat and salt transports are not (see Figures 11a-11i and Table 3). The "in" branch of the eddy brings deep-sea water (with low Chl- $a$ content) onto 


\section{QAGU Journal of Geophysical Research: Oceans}
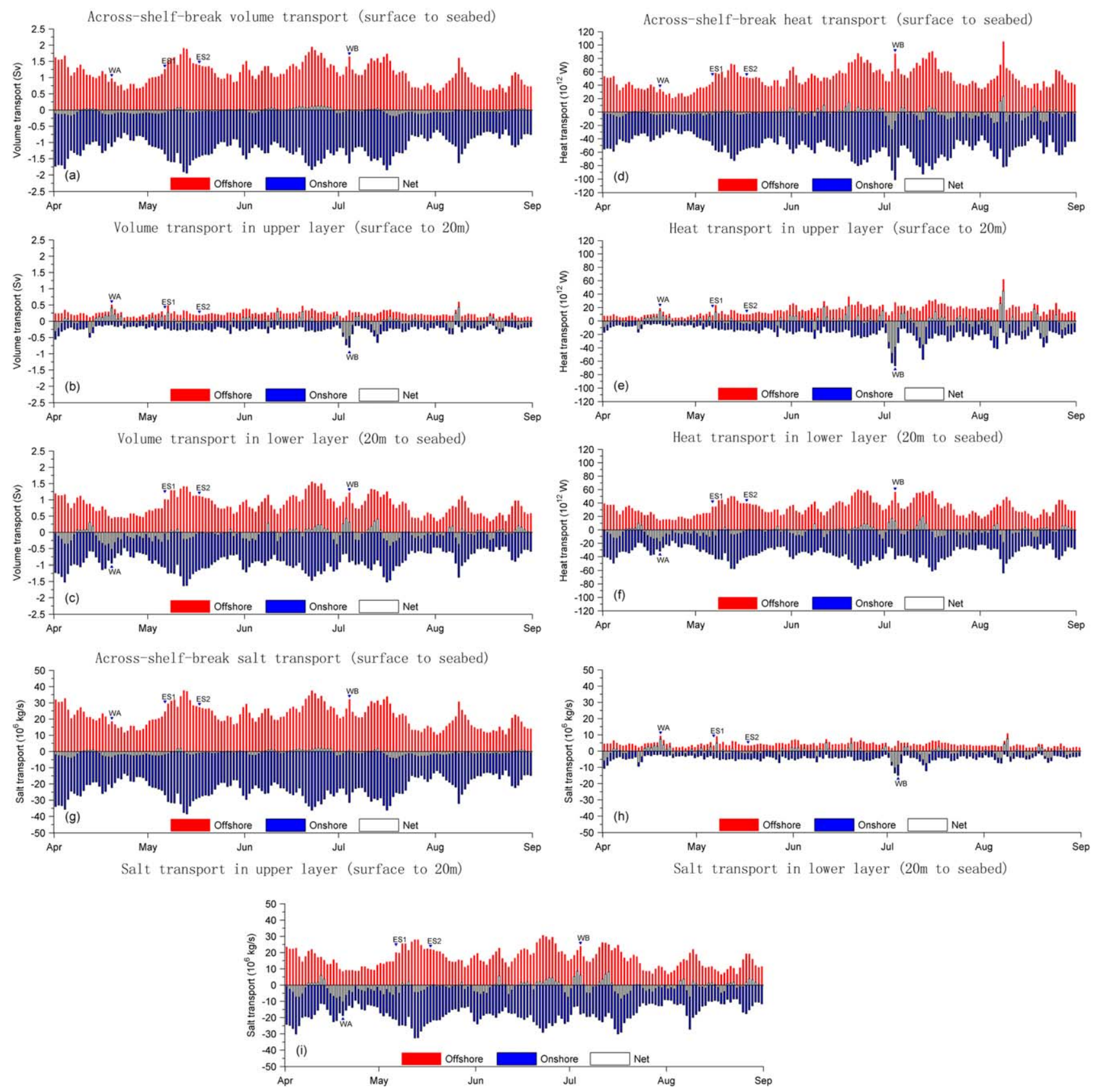

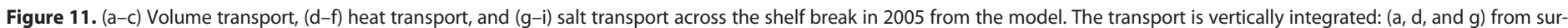
face to seabed; (b, e, and h) from surface to $20 \mathrm{~m}$; and (c, f, and i) from $20 \mathrm{~m}$ to the seabed. The critical cases discussed in the text are labeled as WA, ES1, ES2, and WB.

the shelf, this water mixes with the native shelf waters, and the "out" branch of the same eddy exports the water of a similar volume but with different properties (e.g., high $\mathrm{Chl}-a$ content). This process is clearly seen in the satellite image in Figure 2.

For comparison, the two wind events generated the transports in the top $20 \mathrm{~m}$ of $0.32 \mathrm{~Sv}$ (offshore, Event WA) and $-0.55 \mathrm{~Sv}$ (onshore, Event WB), which were similar or even higher than the eddy-induced transport (see Table 1). It should be noted that these figures also include a small contribution from the eddy and meander-induced transports in the top $20 \mathrm{~m}$ (see Figure 6a). However, due to the short duration, the two wind events transported only $0.22 \times 10^{12} \mathrm{~m}^{3}$ of the shelf water to the deep-sea region (Event WA, top 20 
$\mathrm{m}$ ) and $0.19 \times 10^{12} \mathrm{~m}^{3}$ of the deep-sea water onto the shelf (Event WB, top $20 \mathrm{~m}$ ), which is only about $7 \%$ of that of the Sevastopol Eddy (which transported at all depths).

In an addition to the anticyclonic eddy, there were other dynamic features affecting the across-shelf exchange. First, the meandering Rim Current could facilitate the exchange, not only by impinging onto the shelf break but also by enhancing the anticyclonic eddy when it strengthens the eddy orbital velocity (e.g., in the snapshot ES2; Figures $9 \mathrm{~b}$ and 9c). The maximum orbital velocity in the southwestern periphery of the eddy (influenced by the meander) was $50 \mathrm{~cm} \mathrm{~s}^{-1}$, as compared to $40 \mathrm{~cm} \mathrm{~s}^{-1}$ in the northeastern periphery. Hence, the eddy-induced onshore transport was facilitated by the meander (see section 3.1.3). As in all other cases, the localized imbalance between onshore and offshore transports generated by the eddy during the event ES2 was compensated at other segments of the boundary (see Figure 9e), so that the net transport across the whole boundary (shown in white in Figure 11a) is significantly smaller than onshore (shown in blue) and offshore (shown in red) transports on their own. The impinging of the Rim Current meander onto the shelf is clearly seen in the velocity maps on 17 May (Figures 9b and 9c). Some smaller, submesoscale eddies also contributed to the cross-shelf exchange (see Figure 10c); however, their contribution was much smaller compared to the Sevastopol Eddy, due to their small horizontal and temporal scales and weak orbital velocities. In addition, there is a coastal current contributing to the exchange between the NW shelf and the rest of the sea in the areas where the shelf becomes narrow, i.e., near the Crimean peninsula and the cape Kaliakra (Figure 1), This current is evident during the strong wind events and is much weaker during the periods of calm weather. The coastal current is flowing northeastward during the event WA and in the opposite direction during the event WB. The effect of the coastal current on shelf-deep sea exchange is seen in Figure $6 \mathrm{a}$ as small red (outward flowing) patches at $44.7^{\circ} \mathrm{N}$ on 19 April and $43.2^{\circ} \mathrm{N}$ on 4 July.

As expected, the various cross-shelf break transport processes resulted in a nearly zero balance of volume entering/leaving the shelf across the enclosed boundary (shelf break plus the two short segments connecting the shelf break and the coast). The average total offshore transport across the shelf boundary for the period 1 April to 31 August was 1.14 Sv, with a small imbalance with the onshore transport of only 3.4\%, which was caused by river discharges, precipitation minus evaporation, and computational noise.

As the long-lived anticyclonic mesoscale eddies are an ubiquitous feature of the Black Sea circulation [Sur and Ilyin, 1997; Ginzburg et al., 2002a, 2002b; Karabashev et al., 2006; Stanev and Kandilarov, 2012], one could expect that the eddy-induced transport plays a significant role in shaping the properties of the shelf waters in the Black Sea in general and is not specific to the year 2005.

The time line of cross-shelf exchanges for the whole warm season (1 April to 31 August) is shown in Figure 11 , separately for the upper $20 \mathrm{~m}$, the subsurface layer ( $20 \mathrm{~m}$ to bottom) and the for the entire water column from surface to bottom. The graphs are obtained by integrating volume, heat, and salt fluxes along the enclosed boundary. The graphs show incoming and outgoing transports separately as well as the balance between them.

The volume transport integrated from the entire water column varies gently over the warm period (Figure 11a). Five periods have persistently strong (higher than $0.9 \mathrm{~Sv}$ ) daily mean transport: 1-3 April, 5-13 May, 19-26 June, 3-5 July, and 10-16 July. The period of enhanced transports (beginning of May to mid-July) correspond to the periods of greater eddy activity and Rim Current meandering. The transports at the end of April and after 20 July are relatively small.

The wind events WA and WB are clearly seen in Figure 11b, that shows the transports in the upper $20 \mathrm{~m}$ of the water. Figures $11 \mathrm{~b}$ and 11c show that variability of transports in the upper layer and below are different in terms of both their values and the pattern. As primary production is mostly concentrated in the top 20 $\mathrm{m}$, the volume transport in the upper layer may have a greater significance on the assessment of the state of the ecosystem, than the overall transports.

The across-shelf exchanges contribute to the variation of heat (Figures $11 \mathrm{~d}-11 \mathrm{f}$ ) and salt (Figures 11g-11i) content on the shelf. Coherent patterns of variability in the top $20 \mathrm{~m}$ and the lower layer correspond to eddy-meander activities (see snapshots ES1 and ES2) while the wind dominated events tend to produce an antisymmetric picture due to variation in the flow within the Ekman layer and below. The most significant heat and salt transports take place in the layer below $20 \mathrm{~m}$, due to its greater thickness compared to the top Ekman layer. 


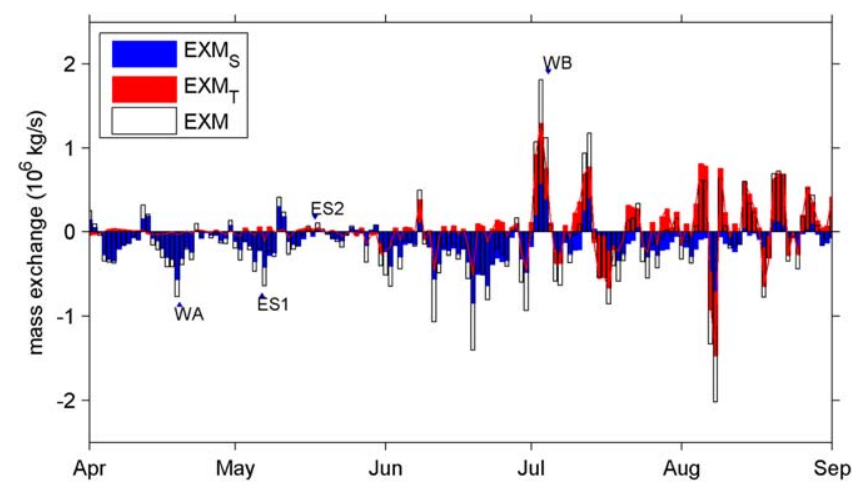

Figure 12. Contribution to mass exchange (EXM) across the shelf break (positive for offshore) by salinity $\left(E X M_{S}\right)$ and temperature $\left(E X M_{T}\right)$. Values are integrated over the enclosed boundary encircling the shelf and over the entire water column. The letter labels mark the dates of the four events discussed individually in section 3.1.
The exchange of mass (as defined in section 3.2) due to heat and salt transport is shown in Figure 12 as a function of time. The timeline of mass transport is different from the volume transport discussed above due to variations of seawater density. Climatological data [Suvorov et al., 2003] show that throughout the year shelf waters are less dense than deep-sea waters. While exchanges of waters with different density across the shelf break generally contribute to dissolution of the density gradient between the shelf and deep sea,

in some cases they result in the enhancement of this gradient. This conclusion looks paradoxical, but it has a straightforward explanation. The shelf is generally colder, less saline, and less dense than the deep Black Sea. Heat exchanges reduce the temperature gradients and make the shelf warmer, and hence less dense. The reduction in shelf water density (which on average is already lower than the deep sea, see Figures 3e3f) makes the density contrast stronger. On the other hand, mixing of salinity makes the shelf waters more saline and hence more dense, thus reducing the density contrast. Integrated over the whole period (1 April to 31 August) the heat transport reduces the average shelf water density by $0.16 \mathrm{~kg} \mathrm{~m}^{-3}$, while salinity transport increases it by $0.67 \mathrm{~kg} \mathrm{~m}^{-3}$ (Table 3). However, there are periods (e.g., 3-5 August) when the heat transport dominates over the salt transport resulting in the net reduction of shelf water density, i.e., enhancement of density contrast (Figure 12).

During the wind event WA (upwelling) the mass transport was negative, i.e., in the onshore direction, and the major contribution to density transport was due to salinity (Figure 12, blue bars). The physical mechanism behind this is that fresher surface waters were replaced by more saline deeper waters that were carried in by the compensating flow. The temperature difference across the shelf break in April was not large, so the heat exchange was relatively small. The situation was dramatically different during the downwelling wind event WB (1-4 July). In this case, warmer surface waters off of the shelf break was brought onto the shelf, making the shelf water less dense and hence enhancing rather than reducing the density gradient between the shelf and the deep-sea region. We see that the complex nature of across-shelf exchange in the Black Sea includes a less intuitive process of enhancing the density gradient and hence contributing to sustaining the shelf break front. During Event WB, the exchanges of salinity also strengthened the gradient (via reducing the density of the shelf waters) as the salinity of incoming surface waters off of the shelf break was lower than the salinity of deeper (below $20 \mathrm{~m}$ ) shelf waters if they were transported out across the shelf break. Figure 12 shows that between 1 April and 30 June the cross-shelf break exchange mainly weakened the gradient between the shelf and the deep-sea region, while the exchange between 1 July and 31 August mainly enhanced the density gradient by making the shelf waters less dense.

Our results show that the exchange across the shelf break during the biologically productive season April to September are quite significant and hence are vital for the health of the NW shelf ecosystem. The degradation of the NW shelf ecosystem in the Black Sea in recent decades has been largely attributed to the supply of nutrients and contaminants by the rivers and coastal activities [Mee, 1992; Cociasu et al., 1996; Mee et al., 2005; Yunev et al., 2007]. The renewal of shelf water across the shelf break not only leads to the reduction of eutrophication on the NW shelf, but also may modify the ratio of different nutrients there as the utilization of nutrients occurs mainly in the euphotic zone.

The cumulative effect of the offshore transport in the biologically active top $20 \mathrm{~m}$ layer for one month $\left(0.62 \times 10^{12} \mathrm{~m}^{3}\right)$ is approximately equivalent to $60 \%$ of the total volume of the top $20 \mathrm{~m}$ over the 


\section{QAGU Journal of Geophysical Research: Oceans}

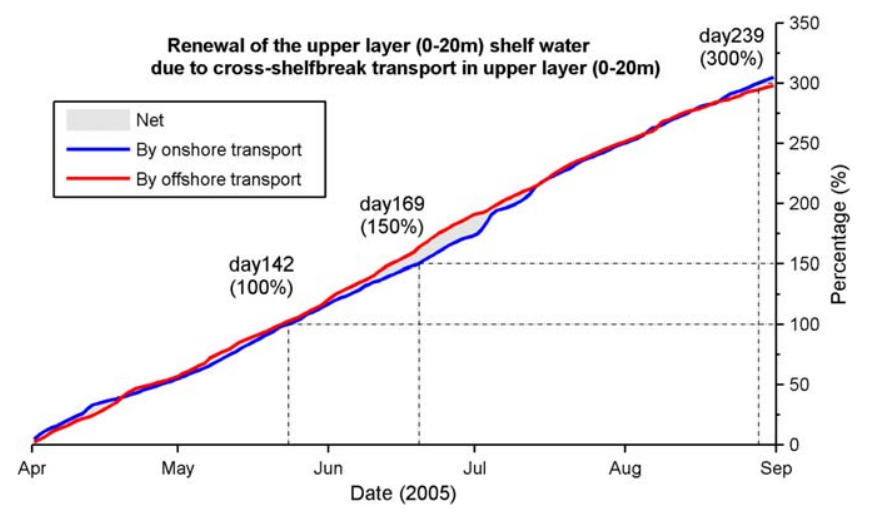

Figure 13. Renewal rate of the NW shelf water in the upper layer (surface to $20 \mathrm{~m}$ ) caused by the exchange across the enclosed boundary. whole NW shelf (see Figure 13). Over the entire warm period (1 April to 31 August), the transferred volume of water in the top $20 \mathrm{~m}$ is equivalent to 3 times of the volume of the shelf waters in the same layer.

The wind strength over the NW shelf decreases from April-May to June-July; however, the trend in shelf water renewal is nearly linear (see Figure 13). This result supports the argument that the most efficient mechanism of

cross-shelf exchange is related to the mesoscale dynamics in the Black Sea, namely, eddies and meanders. The practical consequence of this is that only eddy-resolving ocean models could adequately model the shelf waters.

From the beginning of April to mid-May (which approximately corresponds to the period of the spring phytoplankton bloom), the amount of water entered the shelf from the deep-sea region within the depth range of $0-20 \mathrm{~m}$ was equivalent to $100 \%$ of the total volume of shelf waters in the same depth range (Figure 13), manifesting quick renewal of biologically productive waters. This estimate is consistent with the previous study of phytoplankton variability suggested by McQuatters-Gollop et al. [2008], who showed that a strong lag correlation of $\mathrm{Chl}-\mathrm{a}$ distribution on the shelf does not exceed 1 month.

\section{Conclusion}

This study analyzes the physical mechanisms and quantifies the transport of water, heat, and salt across the NW Black Sea shelf break using a 3-D eddy-resolving ocean circulation model over the period of 1 April to 31 August 2005. Despite the inhibiting action of the steep continental slope, the exchanges across the NW shelf break contribute to fast renewal of shelf waters and to transport of eutrophied surface water masses into the deep-sea region. Two physical processes-a long-lived anticyclonic eddy together with menders associated the Rim Current and wind-driven Ekman transport-are shown to be the major contributing factors to the across-shelf exchange.

Due to the high intensity of cross-shelf exchanges, the average renewal time for the vast NW shelf in the Black Sea was only 28 days. During the short but intensive wind events of 15-22 April and 1-4 July, 23\% and $16 \%$ of shelf waters, were moved into the deep-sea region, respectively. However, a much larger crossshelf transport was generated by a long-lived anticyclonic eddy impinging on the shelf, sometimes assisted by a cyclonic meander of the Rim Current. Over 69 days between 23 April and 30 June, $2.84 \times 10^{12} \mathrm{~m}^{3}$ of water ( $102 \%$ of the entire volume of the shelf waters) was transported out of the shelf and a similar amount onto the shelf.

Cross-shelf break exchange can influence the density gradient between the shelf (typically less dense) and the deep-sea region. From 1 April to the end of June, the exchange smoothed the gradient, as one would expect from the "turbulent" exchange processes. What is less intuitive is that the exchange sharpened the gradient between the shelf and the deep-sea region in July-August. This was mostly due to a complex interplay of 3-D circulation and stratification of the water column: the warmer (and less dense) deep-sea surface water was transported onto the shelf, while higher salinity (and hence denser) subsurface water left the shelf for the deep-sea region. Over the whole study period, salt exchange increased the average density of the shelf waters by $0.67 \mathrm{~kg} \mathrm{~m}^{-3}$ while heat exchange decreased the average density over the shelf by 0.16 $\mathrm{kg} \mathrm{m}^{-3}$. 


\section{QAGU Journal of Geophysical Research: Oceans}

As the mesoscale features significantly contribute to the across-shelf exchange in the biologically active euphotic layer, mesoscale dynamics should be taken into account in assessing the state of the NW shelf ecosystem in the Black Sea.

\section{Acknowledgments}

This work was carried out during FZ's visit to the Marine Institute at the University of Plymouth, which was sponsored by Zhejiang Association for International Exchange of Personnel (151 Program). This study was supported by the National Basic Research Program from the Ministry of Science and Technology of China (grant 2011CB409803), the Natural Science Foundation of China (grant 41276031), Zhejiang Provincial Natural Science Foundation (grant LY12D06005), EU PERSEUS (FP7OCEAN-2011-287600), EU MyOCEAN (FP7-SPA.2011.1.5-01 grant 283367), the University of Plymouth Marine Institute Innovation Fund, and Public Science, and Technology Research Funds Projects of Ocean (grant 201205015).

\section{References}

Bauer, J. E., and E. R. Druffel (1998), Ocean margins as a significant source of organic matter to the deep open ocean, Nature, 392(6675), 482-485, doi:10.1038/33122.

Biggs, D. C., A. E. Jochens, M. K. Howard, S. F. DiMarco, K. D. Mullin, R. R. Leben, F. E. Muller-Karger, and C. Hu (2005), Eddy forced variations in on- and off-margin summertime circulation along the 1000-m isobath of the northern Gulf of Mexico, 2000-2003, and links with sperm whale distributions along the middle slope, in Circulation in the Gulf of Mexico: Observations and Models, Geophys. Monogr. Ser., vol. 161, edited by W. Sturges and A. Lugo-Fernandez, pp. 71-85, AGU, Washington, D. C., doi:10.1029/161GM06.

Biscaye, P. E., and R. F. Anderson (1994), Fluxes of particulate matter on the slope of the southern Middle Atlantic Bight: SEEP-II, Deep Sea Res., Part II, 41(2-3), 459-509, doi:10.1016/0967-0645(94)90032-9.

Biscaye, P. E., C. N. Flagg, and P. G. Falkowski (1994), The shelf edge exchange processes experiment, SEEP-II: An introduction to hypotheses, results and conclusions, Deep Sea Res., Part II, 41(2), 231-252, doi:10.1016/0967-0645(94)90022-1.

Blinkov, V. A., V. A. Dulov, and S. V. Stanichny (2002), Mushroom-like currents above the depth drop in Black Sea northwest part: Remote and in situ measurements [in Russian], in Systems for Environment Control, edited by V. N. Eremeev et al., pp. 406-412, Marine Hydrophysical Institute (MIH), Sevastopol, Ukraine.

Brink, K. H., J. M. Bane, T. M. Church, C. W. Fairall, G. L. Geernaert, D. E. Hammond, S. M. Henrichs, C. S. Martens, C. A. Nittrouer, and D. P. Rogers (1992), Coastal ocean processes: A science prospectus, WHOI-92-18, pp. 1-107, Woods Hole Oceanogr. Inst., Woods Hole, Mass.

Bulgakov, S. N., and V. M. Kushnir (1996), Vertical structure of the current field in the Northern Black Sea, Oceanol. Acta, 19(5), 513-522.

Caddy, J. F., and A. Bakun (1995), Marine catchment basins and anthropogentic effects on coastal fishery ecosystems, in Effects of Riverine Inputs on Coastal Ecosystems and Fisheries Resources, FAO Fish. Tech. Pap. 349, pp. 119-133, Food and Agric. Organ. of the U. N., Rome.

Cociasu, A., L. Dorogan, C. Humborg, and L. Popa (1996), Long-term ecological changes in Romanian coastal Waters of the Black Sea, Mar. Pollut. Bull., 32(1), 32-38, doi:10.1016/0025-326X(95)00106-W.

Dinniman, M. S., J. M. Klinck, and W. O. Smith Jr. (2003), Cross-shelf exchange in a model of the Ross Sea circulation and biogeochemistry, Deep Sea Res., Part II, 50(22), 3103-3120, doi:10.1016/j.dsr2.2003.07.011.

Edwards, K. P., R. Barciela, and M. Butenschön (2012), Validation of the NEMO-ERSEM operational ecosystem model for the North West European Continental Shelf, Ocean Sci., 8(6), 983-1000, doi:10.5194/os-8-983-2012.

Ezer, T., and G. L. Mellor (1994), Diagnostic and prognostic calculations of the North Atlantic circulation and sea level using a sigma coordinate ocean model, J. Geophys. Res., 99(C7), 14,114-14,159, doi:10.1029/94JC00859.

GEF-UNDP report (2006), Trends in nutrient loads from the Danube river and trophic status of the Black Sea, Joint Report of the GEF-UNDP Black Sea Ecosystem Recovery Project and the GEF-UNDP Danube Regional Project, UNDP/ GEF Danube Regional Project, Vienna, Austria, $26 \mathrm{pp}$.

Ginzburg, A. I., A. G. Kostianoy, N. P. Nezlin, D. M. Soloviev, and S. V. Stanichny (2002a), Anticyclonic eddies in the northwestern Black Sea, J. Mar. Syst., 32(1), 91-106, doi:10.1016/S0924-7963(02)00035-0.

Ginzburg, A. I., A. G. Kostianoy, V. G. Krivosheya, N. P. Nezlin, D. M. Soloviev, S. V. Stanichny, and V. G. Yakubenko (2002b), Mesoscale eddies and related processes in the northeastern Black Sea, J. Mar. Syst., 32(1-3), 71-90, doi:10.1016/S0924-7963(02)00030-1.

Guo, X., Y. Miyazawa, and T. Yamagata (2006), The Kuroshio onshore intrusion along the shelf break of the East China Sea: The origin of the Tsushima Warm Current, J. Phys. Oceanogr., 36(12), 2205-2231, doi:10.1175/JPO2976.1.

Houghton, R. W., F. Aikman, and H. W. Ou (1988), Shelf-slope frontal structure and cross-shelf exchange at the New England shelf-break, Cont. Shelf Res., 8(5), 687-710, doi:10.1016/0278-4343(88)90072-6.

Hovmöller, E. (1949), The trough-and-ridge diagram, Tellus, 1(2), 62-66, doi:10.1111/j.2153-3490.1949.tb01260.x.

Huthnance, J. M. (1995), Circulation, exchange and water masses at the ocean margin: The role of physical processes at the shelf edge, Prog. Oceanogr., 35(4), 353-431, doi:10.1016/0079-6611(95)80003-C.

Huthnance, J. M., H. M. Van Aken, M. White, E. D. Barton, B. Le Cann, E. F. Coelho, E. Alvarez Fanjul, P. Miller, and J. Vitorino (2002), Ocean margin exchange-Water flux estimates, J. Mar. Syst., 32(1-3), 107-137, doi:10.1016/S0924-7963(02)00034-9.

Huthnance, J. M., J. T. Holt, and S. L. Wakelin (2009), Deep ocean exchange with west-European shelf seas, Ocean Sci., 5(4), 621-634, doi: 10.5194/os-5-621-2009.

Jaoshvili, S. (2002), The Rivers of the Black Sea, Tech. Rep. 71, edited by I. Khomerki, G. Gigineishvili, and A. Kordzadze, pp. 1-58, Eur. Environ. Agency, Copenhagen.

Johnson, J., and P. Chapman (2011), Deep ocean exchange with the shelf (DOES), Ocean Sci., 7, 101-109, doi:10.5194/os-7-101-2011.

Karabashev, G. S., M. A. Evdoshenko, and S. V. Sheberstov (2006), Normalized radiance spectrum as a water exchange event diagnostic, Int. J. Remote Sens., 27(9), 1775-1792, doi:10.1080/01431160500380505.

Kirincich, A. R., and J. A. Barth (2009), Time-varying across-shelf Ekman transport and vertical eddy viscosity on the inner shelf, J. Phys. Oceanogr., 39(3), 602-620, doi:10.1175/2008JPO3969.1.

Kopelevich, O. V., S. V. Sheberstov, O. Yunev, O. Basturk, Z. Z. Finenko, S. Nikonov, and V. I. Vedernikov (2002), Surface chlorophyll in the Black Sea over 1978-1986 derived from satellite and in situ data, J. Mar. Syst., 36(3-4), 145-160, doi:10.1016/S0924-7963(02)00184-7.

Korotaev, G., T. Oguz, A. Nikiforov, and C. Koblinsky (2003), Seasonal, interannual, and mesoscale variability of the Black Sea upper layer circulation derived from altimeter data, J. Geophys. Res., 108(C4), 3122, doi:10.1029/2002JC001508.

Latun, V. S. (1990), Anticyclonic eddies in the Black Sea in the summer of 1984, Sov. J. Phys. Oceanogr., 1(4), 279-286, doi:10.1007/ BF02197397.

Madec, G. (2008), NEMO Ocean Engine, Note du Pole de Modélisation, Inst. Pierre-Simon Laplace, Paris, France, ISBN:1288-1619.

Matsuno, T., J. Lee, and S. Yanao (2009), The Kuroshio exchange with the South and East China Seas, Ocean Sci., 5(3), 303-312, doi:10.5194/ os-5-303-2009.

McQuatters-Gollop, A., L. D. Mee, D. E. Raitsos, and G. I. Shapiro (2008), Non-linearities, regime shifts and recovery: The recent influence of climate on Black Sea chlorophyll, J. Mar. Syst., 74(1), 649-658, doi:10.1016/j.jmarsys.2008.06.002.

McWilliams, J. C. (1984), The emergence of isolated coherent vortices in turbulent flow, J. Fluid Mech., 146, 21-43, doi:10.1017/ S0022112084001750.

Mee, L. D. (1992), The Black Sea in crisis: A need for concerted international action, Ambio, 21(4), 278-286. 
Mee, L. D., J. Friedrich, and M. T. Gomoiu (2005), Restoring the Black Sea in times of uncertainty, Oceanography, 18(2), 32-43.

Nezlin, N. P., A. G. Kostianoy, and M. Gregoire (1999), Patterns of seasonal and interannual changes of surface chlorophyll concentration in the Black Sea revealed from the remote sensed data, Remote Sens. Environ., 69(1), 43-55, doi:10.1016/S0034-4257(99)00007-3.

Niiler, P. (2009), Ageostrophic circulation in the ocean, in Proceedings of a Workshop on Oceanography in 2025, edited by Deborah Glickson, pp. 73-76, National Academic Press, Washington, D. C.

O'Dea, E. J., A. K. Arnold, K. P. Edwards, R. Furner, P. Hyder, M. J. Martin, J. R. Siddorn, D. Storkey, J. While, and J. T. Holt (2012), An operational ocean forecast system incorporating NEMO and SST data assimilation for the tidally driven European North-West shelf, J. Oper. Oceanogr., 5(1), 3-17.

Oguz, T. (Ed.) (2008), State of the Environment of the Black Sea (2001-2006/7), 448 pp., Referans Çeviri Hizmetleri, Comm. on the Prot. of the Black Sea Against Pollution (BSC) 2008-3, Istanbul, Turkey.

Oguz, T., V. S. Latun, M. A. Latif, V. V. Vladimirov, H. I. Sur, A. A. Markov, E. Özsoy, B. B. Kotovshchikov, V. V. Eremeev, and Ü. Ünlüata (1993), Circulation in the surface and intermediate layers of the Black Sea, Deep Sea Res., Part I, 40(8), 1597-1612, doi:10.1016/09670637(93)90018-X.

Ohlmann, J. C., P. P. Niiler, C. A. Fox, and R. R. Leben (2001), Eddy energy and shelf interactions in the Gulf of Mexico, J. Geophys. Res., 106(C2), 2605-2620, doi:10.1029/1999JC000162.

O'Neill, C. K., J. A. Polton, J. T. Holt, and E. J. O'Dea (2012), Modelling temperature and salinity in Liverpool Bay and the Irish Sea: Sensitivity to model type and surface forcing, Ocean Sci., 8, 903-913, doi:10.5194/os-8-903-2012.

Peliz, Á., A. M. P. Santos, P. B. Oliveira, and J. Dubert (2004), Extreme cross-shelf transport induced by eddy interactions southwest of Iberia in winter 2001, Geophys. Res. Lett., 31, L08301, doi:10.1029/2004GL019618.

Piola, A. R., N. M. Avellaneda, R. A. Guerrero, F. P. Jardón, E. D. Palma, and S. I. Romero (2010), Malvinas-slope water intrusions on the northern Patagonia continental shelf, Ocean Sci., 6(1), 345, doi:10.5194/osd-6-2939-2009.

Pringle, J. M. (2001), Cross-shelf eddy heat transport in a wind-free coastal ocean undergoing winter time cooling, J. Geophys. Res., 106(C2), 2589-2604, doi:10.1029/2000JC900148.

Sarkisian, A. S., and J. E. Sündermann (2009), Modelling Ocean Climate Variability, Springer, Berlin, ISBN:1402092084, doi:10.1007/978-14020-9208-4.

Serra, N., I. Ambar, and D. Boutov (2010), Surface expression of Mediterranean Water dipoles and their contribution to the shelf/slopeOpen ocean exchange, Ocean Sci., 6(1), 191-209, doi:10.5194/os-6-191-2010.

Shapiro, G. I. (2009), Black Sea circulation, in Ocean Currents: A Derivative of Encyclopedia of Ocean Sciences, 2nd ed., edited by J. H. Steele, S. A. Thorpe, and K. K. Turekian, pp. 401-414, Academic, Oxford, U. K.

Shapiro, G. I., S. V. Stanichny, and R. R. Stanychna (2010), Anatomy of shelf-deep sea exchanges by a mesoscale eddy in the North West Black Sea as derived from remotely sensed data, Remote Sens. Environ., 114(4), 867-875, doi:10.1016/j.rse.2009.11.020.

Shapiro, G., M. Luneva, J. Pickering, and D. Storkey (2013), The effect of various vertical discretization schemes and horizontal diffusion parameterisation on the performance of a 3-D ocean model: The Black Sea case study, Ocean Sci., 9(2), 377-390, doi:10.5194/os-9-3772013.

Song, Y., and D. Haidvogel (1994), A semi-implicit ocean circulation model using a generalized topography-following coordinate system, J. Comput. Phys., 115(1), 228-244, doi:10.1006/jcph.1994.1189.

Stanev, E. V., and R. Kandilarov (2012), Sediment dynamics in the Black Sea: Numerical modelling and remote sensing observations, Ocean Dyn., 62(4), 533-553, doi:10.1007/s10236-012-0520-1.

Sur, H. I., and Y. P. Ilyin (1997), Evolution of satellite derived mesoscale thermal patterns in the Black Sea, Prog. Oceanogr., 39(2), 109-151, doi:10.1016/S0079-6611(97)00009-8.

Sur, H. i., E. Özsoy, and Ü. Ünlüata (1994), Boundary current instabilities, upwelling, shelf mixing and eutrophication processes in the Black Sea, Prog. Oceanogr., 33(4), 249-302, doi:10.1016/0079-6611(94)90020-5.

Sur, H. I., E. Özsoy, Y. P. Ilyin, and Ü. Ünlüata (1996), Coastal/deep ocean interactions in the Black Sea and their ecological/environmental impacts, J. Mar. Syst., 7(2), 293-320, doi:10.1016/0924-7963(95)00030-5.

Suvorov, A. M., D. R. Palmer, A. K. Khaliulin, E. A. Godin, and V. N. Belokopytov (2003), Digital atlas and evaluation of the influence of interannual variability on climate analyses, in Proceedings of OCEANS 2003, pp. 990-995, IEEE, San Diego, Calif., doi:10.1109/ OCEANS.2003.178468.

Yunev, O. A., J. Carstensen, S. Moncheva, A. Khaliulin, G. Ærtebjerg, and S. Nixon (2007), Nutrient and phytoplankton trends on the western Black Sea shelf in response to cultural eutrophication and climate changes, Estuarine Coastal Shelf Sci., 74(1), 63-76, doi:10.1016/ j.ecss.2007.03.030

Zaitsev, Y. P. (1992), Recent changes in the trophic structure of the Black Sea, Fish. Oceanogr., 1(2), 180-189, doi:10.1111/j.13652419.1992.tb00036.x.

Zatsepin, A. G., A. I. Ginzburg, A. G. Kostianoy, V. V. Kremenetskiy, V. G. Krivosheya, S. V. Stanichny, and P. Poulain (2003), Observations of Black Sea mesoscale eddies and associated horizontal mixing, J. Geophys. Res., 108(C8), 3246, doi:10.1029/2002JC001390.

Zhao, L., and X. Guo (2011), Influence of cross-shelf water transport on nutrients and phytoplankton in the East China Sea: A model study, Ocean Sci., 7, 27-43, doi:10.5194/os-7-27-2011. 